\title{
Emission of atmospherically significant halocarbons by naturally occurring and farmed tropical macroalgae
}

\author{
E. C. Leedham ${ }^{1}$, C. Hughes ${ }^{1,2}$, F. S. L. Keng ${ }^{3,4}$, S.-M. Phang ${ }^{3,4}$, G. Malin ${ }^{1}$, and W. T. Sturges ${ }^{1}$ \\ ${ }^{1}$ School of Environmental Sciences, University of East Anglia, Norwich Research Park, Norwich, NR4 7TJ, UK \\ ${ }^{2}$ Now at Environment Department, University of York, Heslington, York YO10 5DD, UK \\ ${ }^{3}$ Institute of Ocean and Earth Sciences, University of Malaya, Kuala Lumpur, 50603, Malaysia \\ ${ }^{4}$ Institute of Biological Sciences, University of Malaya, Kuala Lumpur, 50603, Malaysia
}

Correspondence to: E. C. Leedham (e.leedham@uea.ac.uk)

Received: 29 November 2012 - Published in Biogeosciences Discuss.: 9 January 2013

Revised: 23 April 2013 - Accepted: 30 April 2013 - Published: 3 June 2013

\begin{abstract}
Current estimates of global halocarbon emissions highlight the tropical coastal environment as an important source of very short-lived (VSL) biogenic halocarbons to the troposphere and stratosphere, due to a combination of assumed high primary productivity in tropical coastal waters and the prevalence of deep convective transport, potentially capable of rapidly lifting surface emissions to the upper troposphere/lower stratosphere. However, despite this perceived importance, direct measurements of tropical coastal biogenic halocarbon emissions, notably from macroalgae (seaweeds), have not been made. In light of this, we provide the first dedicated study of halocarbon production by a range of 15 common tropical macroalgal species and compare these results to those from previous studies of polar and temperate macroalgae. Variation between species was substantial; $\mathrm{CHBr}_{3}$ production rates, measured at the end of a $24 \mathrm{~h}$ incubation, varied from 1.4 to $1129 \mathrm{pmol} \mathrm{g} \mathrm{FW}^{-1} \mathrm{~h}^{-1}$ ( $\mathrm{FW}=$ fresh weight of sample). We used our laboratory-determined emission rates to estimate emissions of $\mathrm{CHBr}_{3}$ and $\mathrm{CH}_{2} \mathrm{Br}_{2}$ (the two dominant VSL precursors of stratospheric bromine) from the coastlines of Malaysia and elsewhere in South East Asia (SEA). We compare these values to previous top-down model estimates of emissions from these regions and, by using several emission scenarios, we calculate an annual $\mathrm{CHBr}_{3}$ emission of $40\left(6-224 \mathrm{Mmol} \mathrm{Br}^{-1} \mathrm{yr}\right)$, a value that is lower than previous estimates. The contribution of tropical aquaculture to current emission budgets is also considered. Whilst the current aquaculture contribution to halocarbon emissions in this regional is small, the potential exists for substantial increases in aquaculture to make a significant contribution to regional halocarbon budgets.
\end{abstract}

\section{Introduction}

Over the past $30 \mathrm{yr}$, a number of incubation studies have investigated the production and emission of volatile low molecular weight halocarbons including the methyl halides (e.g. methyl iodide, $\mathrm{CH}_{3} \mathrm{I}$ ) and polyhalogenated compounds (e.g. bromoform, $\mathrm{CHBr}_{3}$ ) from polar and temperate macroalgae (seaweeds) (e.g. Baker et al., 2001; Carpenter et al., 2000; Goodwin et al., 1997; Gschwend et al., 1985; Laturnus, 1995; Manley and Dastoor, 1988; Marshall et al., 1999). Such studies have helped to quantify the production of halocarbons by macroalgae and develop our understanding of the complexity and variability involved in these biogenic processes.

Macroalgae concentrate halides from seawater (Küpper et al., 1998; Saenko et al., 1978) and it is believed that these halides act as antioxidants. In particular, iodine chemistry in phaeophytes as a response to oxidative stress at low tide has been well documented. A flux of internal iodine is observed during oxidative stress which can act as an antioxidant both within algal cells and also on the surface of the alga. Intercellular oxidation of iodine via haloperoxidase catalysedreactions in the presence of $\mathrm{H}_{2} \mathrm{O}_{2}$ and other reactive oxygen species forms hypoiodous acids which may then react with nucleophilic acceptors such as ketones to produce halocarbons (Wever et al., 1991; Winter and Moore, 2009). Iodine may also be released onto the algal surface where it reacts with ozone $\left(\mathrm{O}_{3}\right)$ to form molecular iodine $\left(\mathrm{I}_{2}\right)$, which is now thought to be the dominant product from the iodine antioxidant response (Küpper et al., 2008; Palmer et al., 2005). A flux of bromocarbons as a product of a bromine antioxidant 
response has also been reported, incubation studies have shown increased bromocarbon production with the addition of $\mathrm{H}_{2} \mathrm{O}_{2}$ to algal samples and decreases in bromocarbon production with the addition of peroxidase inhibitors (Collen et al., 1994; Pedersen et al., 1996; Wuosmaa and Hager, 1990). Halocarbon production, as a product of an antioxidant response, is consistent with previous work which suggests that environmental stresses such as desiccation, salinity and nutrient depletion influence halocarbon emission rates (Bondu et al., 2008; Mata et al., 2011; Nightingale et al., 1995). The broad suite of halogenated compounds found in, and released from, algae are thought to act as a defence mechanism. They help protect macroalgae from grazing; control bacterial, fungal and microalgal epiphytes; and limit fungal and bacterial infection (La Barre et al., 2010; Paul and Pohnert, 2010; Weinberger et al., 2007).

Field campaigns in temperate regions have demonstrated the potential importance of halogenated products emitted from macroalgae. In particular, organic and inorganic iodine emissions (e.g. $\mathrm{I}_{2}, \mathrm{CH}_{3} \mathrm{I}$ and diiodomethane, $\mathrm{CH}_{2} \mathrm{I}_{2}$ ) influence local atmospheric chemistry (Ball et al., 2010; Chance et al., 2009; Seitz et al., 2010). Biogenic iodinated species in the troposphere have three important impacts; they provide a route for iodine, an essential element for human health, to reach land; they contribute to the production of ultrafine aerosol particles and so potentially contribute to the number and distribution of cloud condensation nucleii and the atmospheric radiation balance; and they alter the balance of oxidising radicals in the troposphere, thereby changing the oxidising capacity of the atmosphere and its ability to processes other gases, including pollutants and greenhouse gases (Saiz-Lopez et al., 2012 and references therein). The inorganic bromine-containing compounds $\left(\mathrm{Br}_{y}\right)$ found in the atmosphere were once thought to be derived entirely from long-lived anthropogenic compounds such as halons and methyl bromide. Recent model and measurement studies, however, have provided evidence that $\mathrm{Br}_{y}$ from shortlived biogenic sources contribute to stratospheric as well as tropospheric ozone chemistry. The potential contribution of such gases to stratospheric bromine is estimated to be in the range of 1-9 ppt, a substantial amount compared to the total stratospheric $\mathrm{Br}_{y}$ abundance of around 20-25 ppt (Dorf et al., 2008; Yang et al., 2005). Due to their shorter atmospheric lifetimes, iodocarbons are believed to contribute only to tropospheric boundary layer chemistry (Montzka et al., 2010).

The short atmospheric lifetime of biogenic halocarbons, on the order of days to months, alongside geographical variation in biogenic sources, leads to temporal and spatial heterogeneity in biogenic production and atmospheric mixing ratios. Current hypotheses suggest tropical emissions may be particularly important due to deep stratospheric convective systems. These systems may provide a rapid transport mechanism delivering short-lived halocarbons and their product gases to the upper troposphere/lower stratosphere (Quack et al., 2004; Salawich, 2006). Within the tropics the coastal zone has been identified as a potentially strong source region. Yokouchi et al. (2005) measured up to $40 \mathrm{ppt}$ of atmospheric $\mathrm{CHBr}_{3}$ along the coast of tropical islands and a decreasing abundance relative to longer-lived halocarbons such as dibromomethane $\left(\mathrm{CH}_{2} \mathrm{Br}_{2}\right)$ away from the coast; a pattern indicative of a localised coastal source such as macroalgae.

Research cruises in tropical waters, however, have tended to consider emissions from oceanic, shelf sea and upwelling areas (Quack and Suess, 1999; Quack et al., 2004; 2007), and no study to date has focused on emissions from coastal tropical macroalgae. Previous temperate and polar research has consistently shown large variations in emissions both between and within macroalgal species, highlighting the need for species-specific measurements in different geographical regions. Different macroalgae species are found in different climatic regions, which could lead to differences in halocarbon production and emission rates. The ratio of rhodophytes (red algae) relative to phaeophytes (brown algae) and chlorophytes (green algae) is greater in the tropics (Santelices et al., 2009). One example is the abundance of kelp species; whilst tropical kelp beds have been observed in deeper waters (from $10 \mathrm{~m}$ ), warmer temperatures and lower nutrient concentrations mean kelps are not found in shallower tropical coastal waters where they would often dominate temperate macroalgal biomass (Graham et al., 2007). Therefore, it seems unlikely that tropical kelps contribute to tidal bursts of iodinated emissions (as seen over exposed kelp beds at low tides in temperate regions) and the associated burst in ultrafine particles (see Mäkelä et al., 2002). Aquaculture is common in the tropics and is set to increase (see Sect. 3.5.4). Seaweed farms perturb the natural diversity and biomass of certain macroalgal species, potentially altering halocarbon emissions. Environmental conditions also vary, for example, the occurrence and rate of herbivory is believed to be greater in the tropics (Cronin et al., 1997).

In this paper, we present the first dedicated study of halocarbon production by a range of tropical macroalgae. Incubations of 15 species from the intertidal zone of peninsular Malaysia were conducted to determine production rates for a range of halocarbons with known biogenic sources. We investigated the effect of incubation time and compared the production rates obtained with existing data from temperate and polar species. Calculated production rates were used to estimate $\mathrm{CHBr}_{3}$ and $\mathrm{CH}_{2} \mathrm{Br}_{2}$ emissions for Malaysian and South East Asian coastal zones, these estimates were then compared to published values. The current and potential future impact of tropical aquaculture on emissions of $\mathrm{CHBr}_{3}$ was also considered. 


\section{Methods}

\subsection{Sample collection}

In September and October 2011, 15 tropical macroalgae species were collected from several sites on the western coast of Peninsular Malaysia; including an intertidal reef, an aquaculture site and a mangrove stand (Fig. 1). Kappaphycus alvarezii was purchased from a small aquaculture site at Pangkor Island, Ulva reticulata was collected from a shrimp farm and Gelidium elegans was obtained from the University of Malaya (UM) hatchery where it is cultivated for use in aquaculture experiments. All other species were naturally occurring in the coastal environment and obtained from rock pools exposed at low tide or by snorkeling in water up to $1 \mathrm{~m}$ deep (see full details in Table 1). Care was taken to select intact, healthy looking specimens with a minimum of epiphytes. Species attached via a holdfast were removed by carefully cutting the holdfast from the substrate, ensuring minimal damage. One to four species were collected during each sampling trip and returned to the UM hatchery facility where they were stored in large tanks of aerated seawater which were changed about every 3 days. Samples were used within a week of collection. Prior to each incubation replicates of an individual species were chosen, again only undamaged specimens were selected. In most cases triplicate samples were used, but for several incubations the quantity of collected material only allowed duplicate measurements (see Table 1). As previous experiments have shown that different sections of some of the larger algae release different amounts of halocarbons (Laturnus, 1996), single whole plants, or multiple smaller plants of filamentous or mat forming algae, were used. In each case, samples of similar mass and appearance were selected. Cladophora sp., a mat forming alga, was removed from the shore in small sections, maintaining the mud substrate to minimise disturbance, and a separate control containing mud and seawater was used for this incubation. Samples from Cape Rachado often had small sea anemones attached, these were gently removed. An individual incubation on anemones alone (species unknown) showed no appreciable halocarbon production (data not shown).

\subsection{Incubation protocol}

Gas-tight incubation vessels comprised modified $500 \mathrm{~mL}$ Erlenmeyer flasks and Dreschel tops as described by Hughes et al. (2011). The Dreschel outlets were capped with $0.2 \mu \mathrm{m}$ Minisart ${ }^{\circledR}$ filters (Sartorius, UK) and plastic Luer-type taps. During incubations all Luer taps were closed and during sample removal one was opened to allow the flask to reequilibrate to atmospheric pressure, with the filter preventing ingress of bacteria, dust or other foreign matter. Filtered seawater $(400 \mathrm{~mL}, 0.2 \mu \mathrm{m}$ filtered sterilised) collected from a coastal site near to Kuala Lumpur was added to each flask leaving a $300 \mathrm{~mL}$ headspace. Seawater from this site was

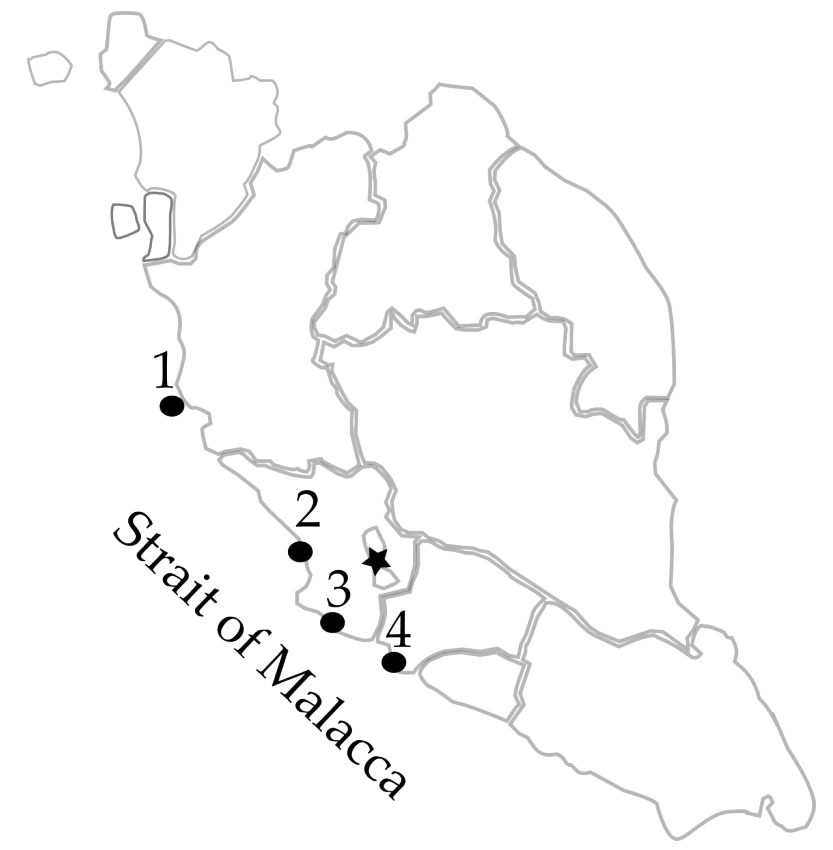

Fig. 1. Location of sampling sites Peninsular Malaysia. $\star=$ Kuala Lumpur (laboratory), $\bullet=$ sampling sites. (1) Seaweed farm, Pangkor Island, Perak. (2) Shrimp farm, Kuala Selangor, Selangor. (3) Mangroves, Morib, Selangor. (4) Port Dickson, Negeri Sembilan; including Cape Rachado, Pantai Dickson and Pantai Purnama.

used for each incubation for standardisation. Algal samples were gently blotted dry and weighed before they were added to the flasks to obtain fresh weight values for use in production calculations. Two control flasks containing filtered seawater only were used for each incubation.

Flasks were transferred to an incubator at $35^{\circ} \mathrm{C}$ which provided $120-130 \mu \mathrm{mol}$ photons $\mathrm{s}^{-1} \mathrm{~m}^{-2}$ constant light via fluorescent tubes (Philips). Jones and Carpenter (2005) reported UV photolysis of $\mathrm{CH}_{2} \mathrm{I}_{2}, \mathrm{CH}_{2} \mathrm{BrI}$ and $\mathrm{CH}_{2} \mathrm{ClI}$ with lifetimes of $10 \mathrm{~min}( \pm 1 \mathrm{~min}), 4.5 \mathrm{~h}( \pm 40 \mathrm{~min})$ and $9 \mathrm{~h}( \pm 2 \mathrm{~h})$, respectively; lifetimes that could be significant within the 4 and $24 \mathrm{~h}$ timescales of our incubations. However, no UVA or UVB light was measured in the incubator (Keng et al., 2013) and therefore, we conclude that UV photolysis was negligible. Incubations lasted $24 \mathrm{~h}, 40 \mathrm{~mL}$ samples were removed for analysis after $4(t 4)$ and $24 \mathrm{~h}(t 24)$. Samples were removed directly into $100 \mathrm{~mL}$ gas-tight syringes using a Luer tap port near the base of each flask, taking care to prevent ingress of air. Samples were analysed immediately. After $t 4$, the $40 \mathrm{~mL}$ removed for sampling was not replenished to avoid dilution or nutrient addition effects. After $t 24$ macroalgae samples were re-weighed, but no significant changes were noted for any of the incubations. Dry weight was calculated by drying samples for 3 days in an oven at $60^{\circ} \mathrm{C}$ followed by $24 \mathrm{~h}$ in a desiccator; a method used extensively by the UM Algae Lab. Losses to the headspace were estimated by calculating the solubility of each halocarbon with data from Sander (1999) 
Table 1. Tropical macroalgae investigated, their collection sites and sample details. $N=$ number of replicates used in incubation study.

\begin{tabular}{|c|c|c|c|c|c|}
\hline Species & $\begin{array}{l}\text { Collection } \\
\text { site }\end{array}$ & $\begin{array}{l}\text { Collection } \\
\text { date }\end{array}$ & $\begin{array}{l}\text { Incubation } \\
\text { date }\end{array}$ & $\begin{array}{l}\text { Sample } \\
\text { composition }\end{array}$ & $\mathrm{n}$ \\
\hline \multicolumn{6}{|l|}{ Rhodophyta } \\
\hline Gelidium elegans & UM culture & 17.10 .11 & 18.10 .11 & Single specimen & 3 \\
\hline Gracilaria changii & Morib mangrove & 19.09.11 & 21.09 .11 & Single specimen & 3 \\
\hline Gracilaria salicornia 1 & Morib mangrove & 19.09.11 & 21.09 .11 & Single specimen & 3 \\
\hline Gracilaria salicornia 2 & Pantai Dickson & 17.10 .11 & 18.10 .11 & Single specimen & 3 \\
\hline Kappaphycus alvarezii & Seaweed farm, Pulau Pangkor & 12.09 .11 & 15.09 .11 & Single specimen & 3 \\
\hline \multicolumn{6}{|l|}{ Phaeophyta } \\
\hline Padina australis & Pantai Purnama & 29.10 .11 & 01.11 .11 & Selection of small plants & 2 \\
\hline Sargassum baccularia & Pantai Purnama & 29.10 .11 & 01.11 .11 & Single specimen & 2 \\
\hline Sargassum binderi & Cape Rachado & 06.10 .11 & 13.10 .11 & Single specimen & 3 \\
\hline Sargassum siliquosum & Pantai Purnama & 29.10 .11 & 01.11 .11 & Single specimen & 2 \\
\hline Turbinaria conoides & Cape Rachado & 06.10 .11 & 10.10 .11 & Single specimen & 3 \\
\hline \multicolumn{6}{|l|}{ Chlorophyta } \\
\hline Bryopsis sp. & Pantai Purnama & 29.10 .11 & 01.11 .11 & Selection of small plants & 2 \\
\hline Caulerpa racemosa & Cape Rachado & 06.10 .11 & 09.10 .11 & Single specimen & 3 \\
\hline Caulerpa sp. & Cape Rachado & 06.10 .11 & 09.10 .11 & Single specimen & 3 \\
\hline Cladophora sp. & Pantai Dickson & 05.10 .11 & 09.10 .11 & Section of algal mat & 3 \\
\hline Ulva reticulata & Shrimp farm, Kuala Selangor & 21.09 .11 & 23.09 .11 & Selection of small plants & 3 \\
\hline
\end{tabular}

and using this to compute partitioning between seawater and headspace. Percentage losses to the headspace at $t 24$ varied between 3 and $13.5 \%$ for all gases with the exception of $\mathrm{CH}_{3} \mathrm{I}$, for which the calculated loss was $30 \%$.

\subsection{Halocarbon analysis}

Analysis was carried out via purge and trap pre-concentration followed by gas chromatography mass spectrometry (GCMS) as described in Hughes et al. (2006). Briefly, samples were passed through $0.7 \mu \mathrm{m}$ Whatman ${ }^{\mathrm{TM}} \mathrm{GF} / \mathrm{F}$ filters directly into a purpose-built purge system. Here they were purged for $15 \mathrm{~min}$ in a $40 \mathrm{~mL} \mathrm{~min}^{-1}$ flow of oxygen-free nitrogen gas and trapped on a stainless steel trap held at $-150^{\circ} \mathrm{C}$ in the headspace of a dewar of liquid nitrogen. Desorption at $100^{\circ} \mathrm{C}$ by immersion of the trap into boiling water transferred the sample in a flow of helium carrier gas along a short transfer line held at $96^{\circ} \mathrm{C}$ to an Agilent $6890 \mathrm{GC}$ fitted with a $60 \mathrm{~m}$ DB-VRX capillary column (J\&W Ltd.; $0.32 \mathrm{~mm}$ diameter, film thickness $1.8 \mu \mathrm{m})$. A 5973 Agilent MS in electron impact single ion mode provided quantification of halocarbons via comparisons with commercial methanolic solution standards that were diluted gravimetrically in high purity methanol to provide a concentration range similar to that seen experimentally. Identification of each halocarbon was via retention time comparison with a known standard using at least two known mass fragments. Regular multi-point calibrations were used to determine experimental concentrations. Two internal standards (deuterated methyl iodide, $\mathrm{CD}_{3} \mathrm{I}$, and ${ }^{13} \mathrm{C}$-dibromoethane, ${ }^{13} \mathrm{C}_{2} \mathrm{H}_{4} \mathrm{Br}_{2}$ ) were added to each sample to monitor and correct for sensitivity drift in the system. The internal standards were checked at the start of each incubation to ensure they were free of target halocarbons which may have contaminated the samples. The 1SD (standard deviation) precision of the system was around $13 \%$. The detection limit of the complete system, at $1-6 \mathrm{pmol} \mathrm{L}^{-1}$ (halocarbon dependant), was below the background halocarbon concentrations seen in the seawater control. Compounds investigated were $\mathrm{CH}_{3} \mathrm{I}$, bromochloromethane $\left(\mathrm{CH}_{2} \mathrm{BrCl}\right), \mathrm{CH}_{2} \mathrm{Br}_{2}$, bromochloromethane $\left(\mathrm{CH}_{2} \mathrm{BrCl}\right)$ chloroiodomethane $\left(\mathrm{CH}_{2} \mathrm{CII}\right)$, dibromochloromethane $\left(\mathrm{CHBr}_{2} \mathrm{Cl}\right)$, bromoiodomethane $\left(\mathrm{CH}_{2} \mathrm{BrI}\right), \mathrm{CHBr}_{3}$ and $\mathrm{CH}_{2} \mathrm{I}_{2}$. Due to the analytical set up, methyl chloride and methyl bromide could not be measured, but previous studies have suggested that production of these methyl halides from macroalgae is small and unlikely to contribute greatly to global emission budgets (Baker et al., 2001).

\section{Results and discussion}

\subsection{The effect of incubation time on production}

Production rates for 10 of the 15 species were calculated at $t 4$ and $t 24$ (see Supplement Table 1). Table 2 shows the ratio between these values for each species. Over $50 \%$ of measurements were significantly higher at $t 4$ compared to $t 24$ (Student's $t$ test, $\mathrm{p}=0.05$, on data which was first 
Table 2. Ratio $t 4: t 24$ halocarbon production rates. Production (pmol $\mathrm{gFW}^{-1} \mathrm{~h}^{-1}$ ) was higher at $t 4$ for all but one occurrence. nm $=$ not measured, $x=$ at one or both time points compound not detected. Production by P. australis, S. baccularia, S. siliquosum and Bryopsis sp. was not measured at $t 4$.

\begin{tabular}{lrrrrrrrrr}
\hline Species & $\mathrm{CH}_{3} \mathrm{I}$ & $\mathrm{CH}_{2} \mathrm{BrCl}$ & $\mathrm{CH}_{2} \mathrm{Br}_{2}$ & $\mathrm{CHBrCl}_{2}$ & $\mathrm{CH}_{2} \mathrm{ClI}$ & $\mathrm{CHBr}_{2} \mathrm{Cl}$ & $\mathrm{CH}_{2} \mathrm{BrI}$ & $\mathrm{CHBr}_{3}$ & $\mathrm{CH}_{2} \mathrm{I}_{2}$ \\
\hline G. elegans & 2.32 & 3.05 & 2.00 & 5.70 & 3.65 & 2.96 & 6.72 & 7.83 & 7.86 \\
G. changii & 2.72 & 16.47 & 11.80 & 3.56 & 7.20 & 3.25 & 13.26 & 3.95 & 3.16 \\
G. salicornia 1 & 3.22 & 5.16 & 3.34 & 1.77 & 8.71 & 1.26 & 6.84 & 3.29 & 6.85 \\
G. salicornia 2 & 2.36 & 12.45 & 10.87 & 4.36 & 13.08 & 3.71 & 26.36 & 5.39 & 14.72 \\
K. alvarezii & $\mathrm{nm}$ & 0.51 & 0.54 & 0.96 & 0.57 & 0.85 & 1.52 & 3.38 & 4.17 \\
S. binderi & 1.45 & 3.04 & 3.10 & 0.73 & 2.95 & 1.40 & 7.87 & 2.61 & 10.76 \\
T. conoides & 0.68 & 0.91 & 2.21 & 3.04 & 0 & 1.81 & 1.15 & 2.13 & 1.03 \\
C. racemosa & 4.98 & $x$ & 0.59 & $x$ & 1.75 & 1.39 & 1.51 & 2.07 & 1.91 \\
Caulerpa sp. & 0.93 & $x$ & 0.08 & $x$ & 1.75 & 1.39 & 1.51 & 2.07 & 1.91 \\
Cladophora sp. & 0.57 & 1.54 & 3.62 & 0.71 & 0.38 & 2.08 & 2.22 & 2.14 & 0.36 \\
U. reticulata & $x$ & $x$ & 2.39 & 4.99 & 8.81 & 6.14 & 4.39 & 6.68 & 6.75 \\
\hline
\end{tabular}

log-normalised to pass Kolmogorov-Smirnov tests of normality at $p=0.05$ ). Exceptions were the two Caulerpa species, both of which showed low overall production rates of less than $5 \mathrm{pmol} \mathrm{g} \mathrm{FW}^{-1} \mathrm{~h}^{-1}$ for all halocarbons. Both time periods show the same trends, with strong and significant correlations $\left(r^{2}=0.43-0.98, p=0.05\right)$ between individual halocarbon and species datasets at $t 4$ and $t 24$ (Fig. 2). No individual halocarbon displayed a distinctive trend that may have indicated non-biogenic loss or production processes, this will be discussed in more detail later. As the $t 4$ and $t 24$ datasets both show the same patterns, from here on only the $t 24$ dataset, which contains data for a greater number of species, will be discussed.

\subsection{Halocarbon production by tropical macroalgae}

T24 production values for each species are represented graphically in Fig. 3. Panels in Fig. 3 are ranked in order, with the highest individual halocarbon emission rate at the top. $\mathrm{CH}_{2} \mathrm{BrCl}$ emission was low for all species and none was detected from Bryopsis sp., Sargassum siliquosum, U. reticulata. Padina australis and Sargassum baccularia. U. reticulata and Caulerpa racemosa showed no discernible production of $\mathrm{CH}_{3} \mathrm{I}$ and $\mathrm{CHBrCl}_{2}$, respectively. Otherwise, all other species produced all halocarbons. The bromocarbons, $\mathrm{CH}_{2} \mathrm{Br}_{2}$ and $\mathrm{CHBr}_{3}$, were produced ubiquitously. Generally $\mathrm{CHBr}_{3}$ was produced in the highest quantities, followed by $\mathrm{CH}_{2} \mathrm{Br}_{2}$. The exceptions to this were the chlorophytes; Caulerpa sp., C. racemosa, and Cladophora sp., which produced $\mathrm{CH}_{2} \mathrm{Br}_{2}$ at a similar or faster rate than $\mathrm{CHBr}_{3}$. A third Caulerpa species, Caulerpa lentillifera, is not included in this study, but also produced higher quantities of $\mathrm{CH}_{2} \mathrm{Br}_{2}$.

The rhodophyte Gracilaria changii was the strongest $\mathrm{CHBr}_{3}$ producer with an average $\mathrm{CHBr}_{3}$ production rate of $1129 \mathrm{pmolg} \mathrm{FW}^{-1} \mathrm{~h}^{-1}$ (range 1037$1272 \mathrm{pmol} \mathrm{g} \mathrm{FW}^{-1} \mathrm{~h}^{-1}$ ). Another Gracilaria species, Gracilaria salicornia was also a strong halocarbon pro- ducer. G. salicornia was incubated twice, using specimens collected from two different sites within a month of each other (Table 1). Mean $\mathrm{CHBr}_{3}$ production in September

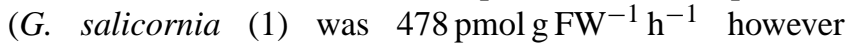
variability was high, with individual incubations producing production rates ranging from $82-875 \mathrm{pmol} \mathrm{g} \mathrm{FW}^{-1} \mathrm{~h}^{-1}$. The second incubation (G. salicornia (2) also demonstrated high production and high variability, with a mean $\mathrm{CHBr}_{3}$ rate of $595 \mathrm{pmol} \mathrm{g} \mathrm{FW}^{-1} \mathrm{~h}^{-1}$ and a range of 298 $791 \mathrm{pmolg} \mathrm{FW}{ }^{-1} \mathrm{~h}^{-1}$. Overall, the rhodophytes we tested tended to be the strongest producers, with $K$. alvarezii producing $\mathrm{CHBr}_{3}$ at a rate of $512.03 \mathrm{pmol} \mathrm{g} \mathrm{FW}^{-1} \mathrm{~h}^{-1}$ (range 479-558 pmol,g, $\mathrm{FW}^{-1}, \mathrm{~h}^{-1}$ ).

High intra-species variability was also seen amongst replicates in previous studies. Carpenter et al. (2000) saw replicate differences within a factor of 2, which they attributed, in part, to fluctuations in light and temperature as their incubations were conducted outdoors. However, fluctuations in environmental variables cannot explain all the variation as our study was conducted under laboratory-controlled light and temperature conditions and variations of the magnitude reported by Carpenter et al. were also observed in our study. Variability was also observed in other incubations conducted under controlled conditions, for example Collen et al. (1994) reported a percentage standard deviation on repeated incubations of up to $129 \%$. This large variability is likely due to variations in both background seawater concentrations and biological variability between replicates. Giese et al. (1999) reported $\mathrm{CHBr}_{3}$ variations in their seawater controls of $\sim 10 \%$ and Laturnus et al. (1996) reported varying production rates from different sections of algal tissue, with, on average, blades producing more $\mathrm{CHBr}_{3}$ than stipes. Variability has been attributed to differences in environmental history (grazing pressure, stress, age) of different samples (e.g. Carpenter et al., 2000). An example of the effect of age can be seen in Mairh et al. (1989) where increasing internal iodine concentrations in older chlorophytes are 

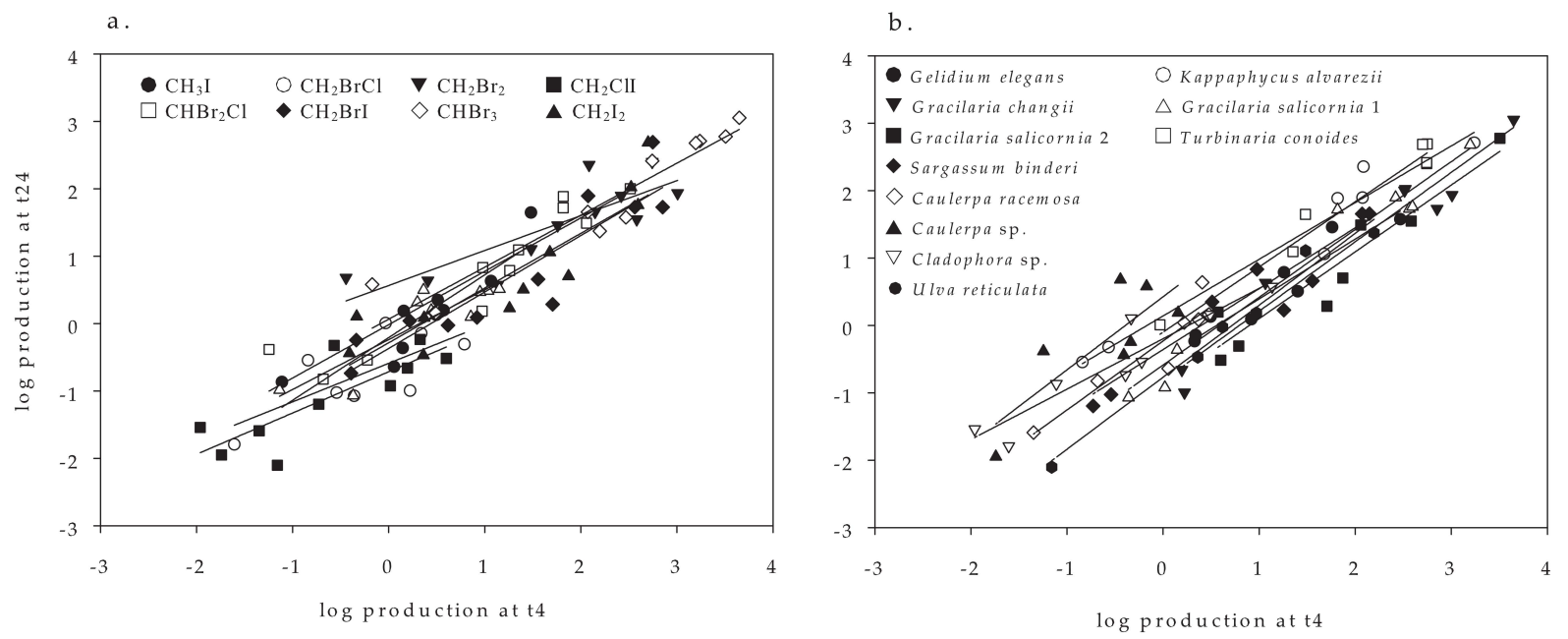

Fig. 2. Correlation between log-normalised production ( $\mathrm{pmolg} \mathrm{FW}^{-1} \mathrm{~h}^{-1}$ ) at $t 4$ and $t 24$ for (a) individual halocarbons and (b) seaweed species.

reported. Variability between replicates is discussed further in Sect. 3.4.

Generally, species that were strong bromocarbon producers also produced relatively high levels of other halocarbons. This was demonstrated by assigning each species a rank (1 lowest, 15 highest) for $\mathrm{CHBr}_{3}$ production. Species were then ranked again, independently, for $\mathrm{CH}_{2} \mathrm{Br}_{2}$ production, then for $\mathrm{CH}_{3} \mathrm{I}$ and so on. The resulting spread of ranks are displayed as a box and whisker plots in Fig. 4. Separate groups can be seen; prolific producers include the rhodophytes and the phaeophyte Turbinaria conoides, most other phaeophytes are in the middle and chlorophytes are generally weaker producers. The strongest bromocarbon producer in this study, $G$. changii, also showed considerable production of other halocarbons, with $\mathrm{CH}_{2} \mathrm{I}_{2}$ production up to 300 times greater than most of the chlorophytes and $\mathrm{CH}_{2} \mathrm{Br}_{2}$ production 2-30 times greater than many of the other species studied. Some species, however, displayed a wide range of ranks. Bryopsis sp., for example, was one of the strongest producers of $\mathrm{CH}_{2} \mathrm{CII}$ with a rank of $13 / 15$, but the weakest producer of $\mathrm{CHBrCl}_{2}$ with a rank of $1 / 15$.

Whilst the rhodophytes produced large quantities of bromocarbons, some of the phaeophytes ranked highly for iodocarbon production. To investigate further, the total proportions of bromine, chlorine and iodine emitted as halocarbons by each species was calculated and Table 3 shows the results with species ranked in order of decreasing total halogen emissions. T. conoides was the strongest producer of all iodine-containing compounds, with a $\mathrm{CH}_{2} \mathrm{I}_{2}$ production rate almost double that for $\mathrm{CHBr}_{3}$. Another phaeophyte, $P$. australis, showed a stronger production rate for $\mathrm{CH}_{3} \mathrm{I}$ than for the bromocarbons. The phaeophytes in general showed a stronger propensity towards production of iodinated compounds, the mean percentage iodine emission for phaeophytes was $35 \%$ compared to $8 \%$ for rhodophytes. This corresponds to temperate studies which report strong iodocarbon emissions from temperate macroalgae such as Laminaria (kelp) (Carpenter and Liss, 2000; Küpper et al., 2008). Chlorophytes also produced a higher percentage of iodine (18\%) when compared to rhodophytes, but as overall production rates were lower for these species, their contribution to local iodine chemistry is probably of less importance. In temperate regions kelps and other phaeophytes often dominate the algal biomass in shallow coastal waters (de Vooys, 1979), but in tropical regions rhodophytes and chlorophytes are often more common (Santelices et al., 2009), potentially shifting the balance of emissions towards brominated species.

With the exception of Bryopsis, the chlorophytes were the weakest producers, with production rates for all halocarbons below $30 \mathrm{pmol} \mathrm{g} \mathrm{FW}^{-1} \mathrm{~h}^{-1}$. Bromocarbons were still produced in the highest quantities, but production rates for iodinated and mixed bromochloro-compounds were generally less than $1 \mathrm{pmol} \mathrm{g} \mathrm{FW}^{-1} \mathrm{~h}^{-1}$ for Ulva, Caulerpa, and Cladophora spp. In common with many chlorophytes, Bryopsis species are fast growing and opportunistic, with the potential to rapidly colonise an area. It has been suggested that halogenated metabolites within algal tissues help protect against epiphytes or grazers (Paul and Pohnert, 2010), perhaps the stronger halocarbon emissions from these species helps protect the algae, facilitating their rapid growth.

Potential triggers for halocarbon emissions, such as grazing or oxidative stress, do not help to explain why different species found in the same environment and subjected to similar environmental conditions show such high variability in their halocarbon production rates. It is possible that some species may rely on other metabolites, for example some tropical Caulerpa species are reported to use high 


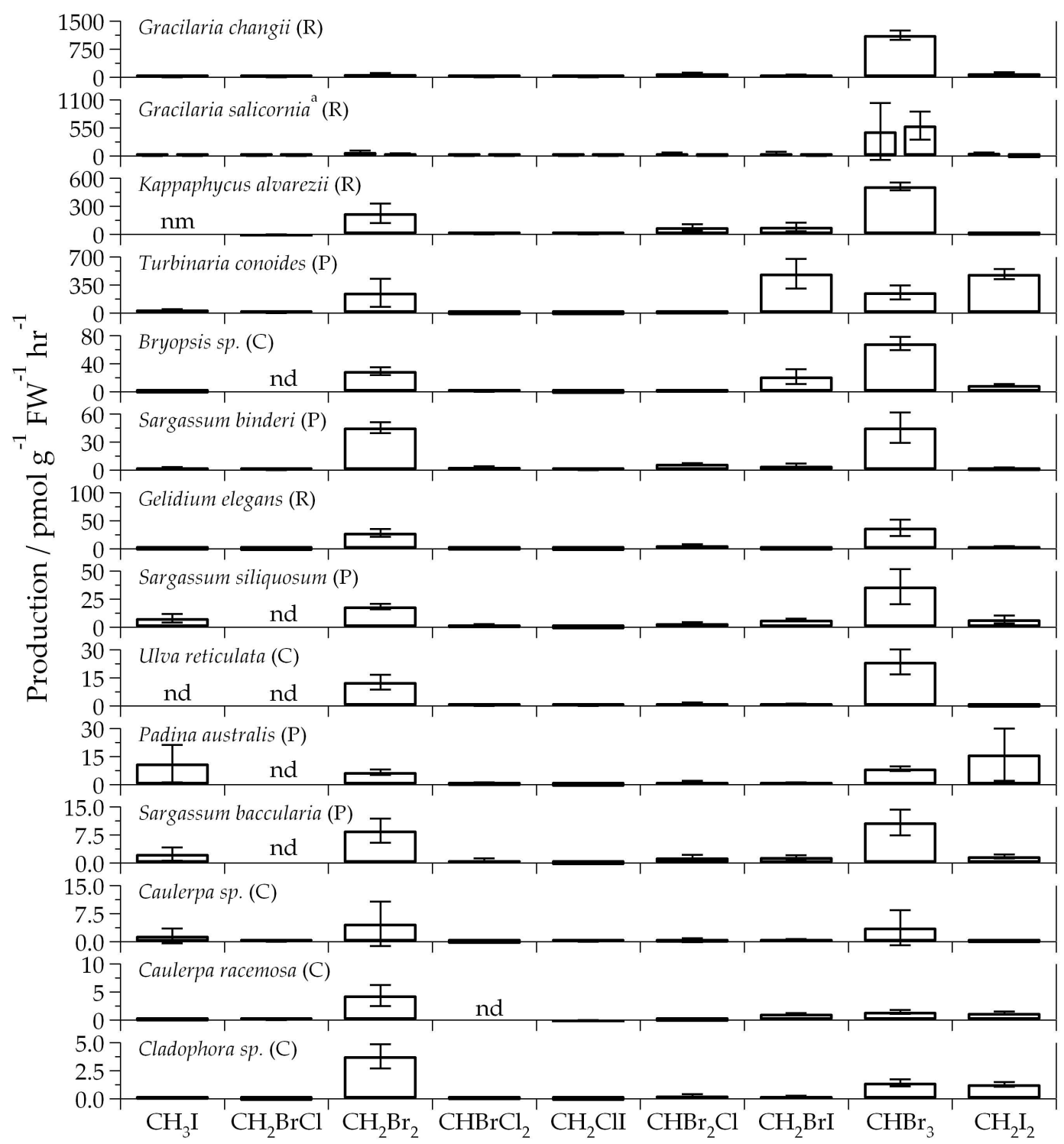

Fig. 3. Halocarbon production by tropical macrophytes measured at $t 24$. Bars are mean production of biological replicates $(n=2$ or 3 , see Table 1) with error bars the $1 \sigma$ standard deviation. $\mathrm{R}=$ rhodophyte, $\mathrm{P}=$ phaeophyte, $\mathrm{C}=$ chlorophyte. "nm" is "not measured" and "nd" is "not detected". (a) G. salicornia was incubated twice (see Table 1).

concentrations of sesquiterpenoid metabolites to deter herbivores (Paul et al., 1987). The Caulerpa species we studied all showed low halocarbon production but no other metabolites were investigated. T. conoides also stood out from the general pattern of rhodophyte $>$ phaeophyte $>$ chlorophyte in terms of production rates. $T$. conoides is in the same phylogenetic family (Sargassaceae) as the weaker producing Sargassum species reported here. Variations between class, genus and species are not unexpected; despite the overarching terms seaweeds or macroalgae they are a diverse and evolutionary distant group, and the evolution and genetic control of halocarbon production is poorly understood.
In the literature to date, halocarbon production is varyingly expressed as both production per unit of fresh weight (FW) or dry weight (DW). Fresh weight may provide an easier basis for scaling up biomass for emission estimates as it better represents natural biomass, whereas dry weight potentially provides easier comparisons between algal species as some algae contain much higher water content than others. The ranking procedure used for Fig. 4 was repeated using production expressed per gram of DW instead of FW. FW and DW derived mean ranks are displayed alongside FW / DW ratios in Table 4. Despite the range of FW / DW ratios seen in this study the ranks assigned to each species 
Table 3. Total mass of halogens emitted as halocarbons during incubation and percentage contribution to this total from bromine, chorine and iodine. Species arranged in order of decreasing total mass of halogen emitted.

\begin{tabular}{lrrrr}
\hline Species & $\begin{array}{r}\text { Total halogens } \\
\text { emitted }(\mathrm{ng})\end{array}$ & $\% \mathrm{Br}$ & $\% \mathrm{Cl}$ & $\% \mathrm{I}$ \\
\hline G. changii & 138748 & 88.9 & 1.1 & 10.0 \\
K. alvarezii & 114395 & 91.8 & 1.5 & 6.7 \\
G. salicornia (mean) & 65655 & 89.1 & 1.3 & 9.7 \\
T. conoides & 40895 & 42.5 & 0.3 & 57.2 \\
Bryopsis sp. & 8419 & 81.3 & 0.3 & 18.4 \\
S. binderi & 4243 & 92.5 & 2.3 & 5.2 \\
G. elegans & 2873 & 92.6 & 1.6 & 5.7 \\
S. siliquosum & 2843 & 79.6 & 1.5 & 18.9 \\
U. reticulata & 2400 & 96.8 & 0.7 & 2.5 \\
S. baccularia & 1548 & 80.1 & 2.0 & 17.9 \\
P. australis & 1104 & 35.0 & 1.0 & 64.1 \\
C. racemosa & 915 & 69.8 & 0.4 & 29.8 \\
Caulerpa sp. & 657 & 83.2 & 1.0 & 15.8 \\
Cladophora sp. & 370 & 74.4 & 1.4 & 24.2 \\
\hline
\end{tabular}

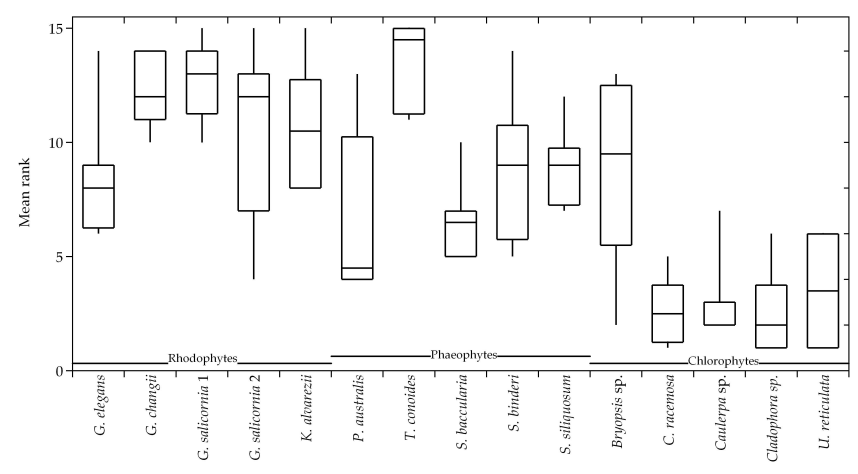

Fig. 4. Production rank box and whisker plots for all halocarbons emitted by each seaweed species. Production data in pmol in $\mathrm{g} \mathrm{FW}^{-1} \mathrm{~h}^{-1}$ at $t 24$ were used to rank the seaweeds for their production of each halocarbon. The lower and upper limits of the boxes represent the 25th and 75th percentiles, the horizontal lines are median values and whiskers represent the 10th and 90th percentiles. Species are ordered by class (rhodophyte, phaeophyte, chlorophyte) and alphabetically with these groups.

and the overall pattern of weak or strong producers remains the same whether fresh or dry weight is used.

\subsection{Correlations between biogenic halocarbons}

Halocarbon correlations from incubation studies could improve our understanding of biological links between halocarbons and their production mechanisms. All log-normalised production values for each halocarbon (except $\mathrm{CHBrCl}_{2}$ which failed normality tests even after log-normalisation) were correlated against one another (Fig. 5) and tested using Pearson's correlation coefficient $(r)$. Significant corre-
Table 4. Changes in mean "production rank" when calculating production using fresh or dry weight. Species are ordered in increasing percentage DW.

\begin{tabular}{lrrr}
\hline \multirow{2}{*}{ Species } & \multicolumn{2}{c}{$\begin{array}{c}\text { r mean } \\
\text { rank }\end{array}$} & $\begin{array}{c}\text { DW as } \\
\% \mathrm{FW}\end{array}$ \\
\cline { 2 - 3 } & $\mathrm{FW}$ & $\mathrm{DW}$ & \\
\hline C. racemosa & 2.5 & 5.6 & 4.3 \\
Caulerpa sp. & 2.7 & 6.8 & 4.8 \\
Bryopsis sp. & 8.3 & 8.6 & 5.9 \\
G. salicornia 1 & 9.6 & 11.2 & 8.0 \\
G. elegans & 8.6 & 6.2 & 8.7 \\
Cladophora sp. & 2.3 & 1.3 & 8.9 \\
K. alvarezii & 12.4 & 13.5 & 9.8 \\
U. reticulata & 3.7 & 2.3 & 11.4 \\
G. changii & 12.3 & 11.0 & 11.4 \\
P. australis & 6.3 & 7.1 & 12.6 \\
S. binderi & 8.6 & 7.4 & 12.9 \\
S. siliquosum & 8.6 & 7.3 & 14.3 \\
T. conoides & 13.3 & 12.8 & 14.4 \\
S. baccularia & 6.1 & 6.0 & 15.4 \\
G. salicornia 2 & 10.7 & 10.0 & 27.0 \\
\hline
\end{tabular}

lations $(p \leq 0.05)$ were common for the polyhalogenated halocarbons, but the mono-halide $\mathrm{CH}_{3} \mathrm{I}$ correlated only with two other iodinated compounds, $\mathrm{CH}_{2} \mathrm{CII}$ and $\mathrm{CH}_{2} \mathrm{I}_{2}$. The strongest correlations were seen for the bromine-containing halocarbons, especially $\mathrm{CHBr}_{3}, \mathrm{CH}_{2} \mathrm{Br}_{2}$ and $\mathrm{CHBr}_{2} \mathrm{Cl}$ with $\mathrm{r}^{2}$ values between $0.79-0.94(p \leq 0.001)$. The weakest correlations that passed the Pearson's $r$ test included correlations between several of the bromine and iodine containing species, for example, $\mathrm{CHBr}_{3}$ and $\mathrm{CH}_{2} \mathrm{I}_{2}\left(r^{2}=0.48, p=\right.$ $0.004)$ and $\mathrm{CH}_{2} \mathrm{ClI}$ and $\mathrm{CHBr}_{2} \mathrm{Cl}\left(r^{2}=0.32, p=0.027\right)$. Our correlations support previous work to define the biochemical production of halocarbons. Methyl halides, in this case $\mathrm{CH}_{3} \mathrm{I}$, are produced via a methyltransferase-mediated reaction between halides and S-adenosyl-L-methionine (SAM), whereas the production of di- and tri-halogenated compounds involves vanadium-dependent haloperoxidases (Bravo-Linares et al., 2010; Goodwin et al., 1997). Manley (2002), summarising his own and others' research, concluded that polyhalomethane production is functional, with polyhalogenated compounds acting as antioxidants, but that methyl halide production does not seem to serve a function and is possibly a by-product of normal metabolism. This difference in functionality supports the lack of correlation we observe between these two groups of halocarbons. However, despite the lack of statistical correlations between the production rates of $\mathrm{CH}_{3} \mathrm{I}$ and the majority of other halocarbons, strong producers (e.g. Gracilaria spp.) produced large quantities of $\mathrm{CH}_{3} \mathrm{I}$ and polyhalogenated compounds. This suggests that links may exist between these two production mechanisms. Further research into potential linkages 


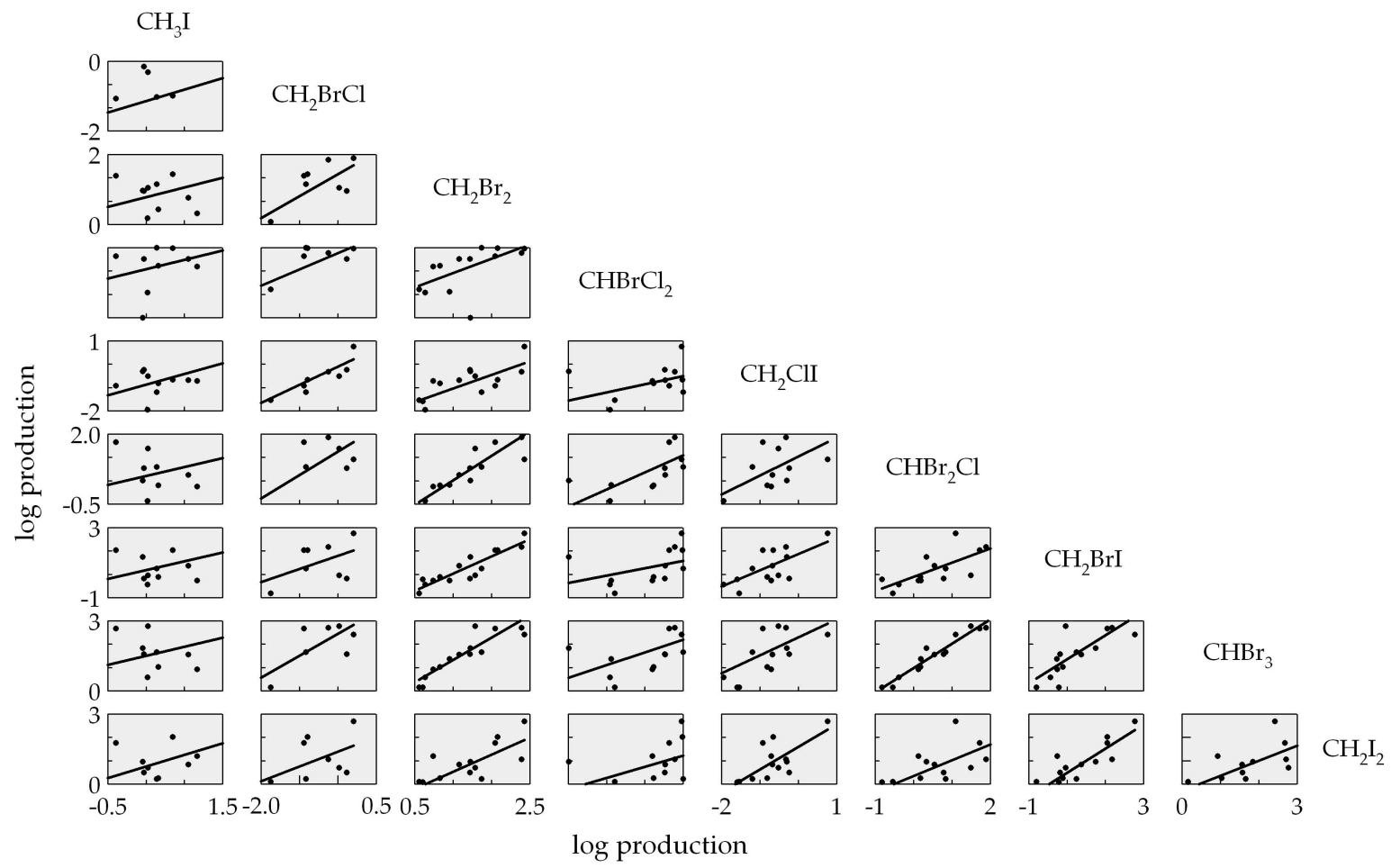

Fig. 5. Halocarbon correlation plots of log-normalised production (pmol $\mathrm{g} \mathrm{FW}^{-1} \mathrm{~h}^{-1}$ ).

between these two production pathways and the mechanisms that control or trigger them is needed.

The highest correlation $\left(r^{2}=0.94, p<0.001\right)$ is between $\mathrm{CHBr}_{3}$ and $\mathrm{CHBr}_{2} \mathrm{Cl}$. Tokarczyk and Moore (1994) suggested that $\mathrm{CHBr}_{2} \mathrm{Cl}$ could be formed from $\mathrm{CHBr}_{3}$ in laboratory cultures of diatoms, although their study did not see a time lag between $\mathrm{CHBr}_{3}$ and $\mathrm{CHBr}_{2} \mathrm{Cl}$ production. Some evidence for the formation of $\mathrm{CHBr}_{2} \mathrm{Cl}$ from $\mathrm{CHBr}_{3}$ may be seen in this study; although both compounds are present at $t 4$ and $t 24$ the ratio of $\mathrm{CHBr}_{3}: \mathrm{CHBr}_{2} \mathrm{Cl}$ decreases from $\sim 18: 1$ at $t 4$ to $\sim 11: 1$ at $t 24$. This could be indicative of conversion occurring during this time. However, nucleophilic substitution should also lead to further conversion of $\mathrm{CHBr}_{2} \mathrm{Cl}$ to $\mathrm{CHBrCl}_{2}$ and this is not seen in our data, the ratio of $\mathrm{CHBr}_{2} \mathrm{Cl}: \mathrm{CHBrCl}_{2}$ remains $\sim 15: 1$ at both $t 4$ and t24. Production of $\mathrm{CH}_{2} \mathrm{ClI}$ from $\mathrm{CH}_{2} \mathrm{I}_{2}$ has also been proposed on the basis of data from incubations and the natural environment (Jones and Carpenter, 2005; Tokarczyk and Moore, 1994). Here $\mathrm{CH}_{2} \mathrm{I}_{2}$ and $\mathrm{CH}_{2} \mathrm{ClI}$ have a relatively strong correlation $\left(r^{2}=0.64, p<0.001\right)$, but we did not see a change in ratio between $t 4$ and $t 24$. Overall, it seems that direct biogenic influence, either through internal halocarbon production or extracellular production via the emission of hypohalous acids which react with organic matter (Manley, 2002), is the important factor determining halocarbon concentrations in these incubations.

Ratios between emissions of pairs of halocarbon gases have been used in the literature to estimate regional and global oceanic halocarbon fluxes. Atmospheric abundance ratios, typically from research cruises, are plotted in pairs against one another. The emissions are scaled to the measured gas for which the absolute emission rate is believed to be known with some degree of confidence, $\mathrm{CH}_{2} \mathrm{Br}_{2}$ in most studies. Such plots normally take a compact linear form, where the gradient reflects a combination of dilution/mixing and atmospheric photochemical removal. The point at which the mixing and chemical loss lines intersect with the correlation between the ratios is deemed to be representative of the source emission ratio. By this method Yokouchi et al. (2005) arrived at "global" emission ratios from seawater for $\mathrm{CHBr}_{3} / \mathrm{CHBr}_{2} \mathrm{Cl}, \mathrm{CHBr}_{3} / \mathrm{CH}_{2} \mathrm{Br}_{2}$ and $\mathrm{CHBr} 2 \mathrm{Cl} / \mathrm{CH}_{2} \mathrm{Br}_{2}$ of 13,9 and 0.7 , respectively, with a $35 \%$ combined error. Using a similar approach, but with measurements at the Cape Verde coast, O'Brien et al. (2009) arrived at similar emission ratios for $\mathrm{CHBr}_{3} / \mathrm{CH}_{2} \mathrm{Br}_{2}$ and $\mathrm{CHBr} 2 \mathrm{Cl} / \mathrm{CH}_{2} \mathrm{Br}_{2}$ of 9 and 0.46 , respectively, based on $95 \mathrm{th}$ percentiles, and 13 and 0.53 , respectively, based on 99th percentiles.

These values can be compared with the halocarbon emission rates determined here for tropical macroalgae. If macroalgae are fully submerged then the emissions are first to seawater, and then to the atmosphere, so the observed emissions will be modified according to the relative solubility of the gases. Using the Henry's Law coefficients for halocarbons in seawater from Moore et al. (1995) gives relative solubilities for $\mathrm{CHBr}_{3} / \mathrm{CHBr}_{2} \mathrm{Cl}, \mathrm{CHBr}_{3} / \mathrm{CH}_{2} \mathrm{Br}_{2}$ and 
$\mathrm{CHBr}_{2} \mathrm{Cl} / \mathrm{CH}_{2} \mathrm{Br}_{2}$ of $1.9,1.5$ and 0.8 , respectively. Correcting this for equilibrium partitioning between water and gas phases results in atmospheric emission ratios of 6,3 and 0.4 , respectively, for the same halocarbon pairs averaged across all macroalgal species measured. If the seaweeds are exposed, and assuming that this exposure does not in itself alter the plant's production or emission, then the corresponding emission ratios would be 11, 4 and 0.3. From our field collection activities, we observed that the seaweeds were mostly submerged, with little exposure at low tide. The exceptions to this were mangrove seaweeds and farmed seaweeds during harvesting. In general, the ratios from the incubations are surprisingly consistent with the open ocean and coastal observations of Yokouchi et al. and O'Brien et al. mentioned above. These similarities do, however, belie a wide range of values for individual seaweed species; the ratio of $\mathrm{CHBr}_{3} / \mathrm{CH}_{2} \mathrm{Br}_{2}$ emission to seawater, for example, varied from 5 to 21 . We therefore caution that in using such "source" ratios to scale regional or global emissions of halocarbons, the uncertainty in the likely range of source emission ratios should be taken into account.

\subsection{Comparison with temperate and polar halocarbon production}

Given that this is the first dedicated study of halocabon production by tropical macroalgae it seemed pertinent to compare these results with existing data for temperate and polar macroalgae. $\mathrm{CHBr}_{3}$ and $\mathrm{CH}_{3} \mathrm{I}$ were selected as case studies and production values assimilated from 21 existing papers. Where production was expressed only per gram of DW production rates were converted (following Carpenter et al., 2000) using DW-FW conversion ratios in Baker et al. (2001) and Bravo-Linares et al. (2010). The resulting production value ranges are displayed alongside the results from our study in Fig. 6. Where errors were quoted alongside production rates these have been translated to error bars on Fig. 6 . Determining error or variability from other studies was not always possible, but, as discussed in Sect. 3.2, previous studies have reported intra-species variability of a similar magnitude to those shown in this study.

The results of the literature comparison (Fig. 6) show a large range of production values, spanning from negligible or no production to $100 \mathrm{pmolg} \mathrm{FW}^{-1} \mathrm{~h}^{-1}$ for $\mathrm{CH}_{3} \mathrm{I}$ and $6000 \mathrm{pmol} \mathrm{g} \mathrm{FW}^{-1} \mathrm{~h}^{-1}$ for $\mathrm{CHBr}_{3}$. Phaeophytes displayed the highest mean production rates for $\mathrm{CH}_{3} \mathrm{I}$, followed by rhodophytes. The chlorophytes showed a considerably lower mean rate; 0.3 pmol $\mathrm{g} \mathrm{FW}^{-1} \mathrm{~h}^{-1}$ compared to around 10 and $4 \mathrm{pmol} \mathrm{g} \mathrm{FW}^{-1} \mathrm{~h}^{-1}$ for phaeophytes and rhodophytes, respectively. Conversely, chlorophytes were, on average, the strongest $\mathrm{CHBr}_{3}$ producers, with a production range of 0-6000 pmol $\mathrm{g} \mathrm{FW}^{-1} \mathrm{~h}^{-1}$ (mean 307) compared to 0-3000 (mean 160) for phaeophytes and 0-5000 (mean 288) for rhodophytes. These differences between classes may provide assistance in creating emissions budgets if the distribu- tion of chlorophytes, phaeophytes and rhodophytes in an area is known. Species that were recorded as producing no $\mathrm{CH}_{3} \mathrm{I}$ or $\mathrm{CHBr}_{3}$ are not displayed in Fig. 6, but the percentage of species that did not produce $\mathrm{CH}_{3} \mathrm{I}$ was higher than for $\mathrm{CHBr}_{3}$ at $\sim 26 \%$ compared to $\sim 10 \%$. The percentage standard deviation across the whole $\mathrm{CH}_{3} \mathrm{I}$ and $\mathrm{CHBr}_{3}$ datasets was similar for both halocarbons at 393 for $\mathrm{CH}_{3} \mathrm{I}$ and 328 for $\mathrm{CHBr}_{3}$.

Sequential measurements from the same incubation flask in this study have highlighted the effect incubation time may have on calculated production. The incubation times used by the studies included in Fig. 6 vary from $30 \mathrm{~min}$ to $48 \mathrm{~h}$, so the incubation time could explain some of the variability between studies investigating the same or similar species. Marshall et al. (1999) and Itoh et al. (1997) observed decreases in halocarbon concentrations between 3-48 h in incubations conducted both in light and dark conditions, both papers proposed biological loss processes. Marshall et al. (1999) conducted further experiments and attributed losses to microbial breakdown whilst Itoh et al. (1997) suggested re-adsorption of the halocarbons onto the algal surface followed by degradation. Our results, which show higher mean production at $t 4$ compared to $t 24$ support these previous findings. The higher values at $t 4$ may also be attributed to incubation preparation, a "burst" of halocarbon emissions upon immersion into the incubation flask due to stress/exposure when the samples are weighed and checked may be unavoidable. Manley and Dastoor (1987) suggested that iodine limitation in the incubation seawater could account for decreases in $\mathrm{CH}_{3} \mathrm{I}$ production as incubations progress. However, as macroalgae can accumulate iodine to far greater concentrations that seawater, up to 30000 times greater for some Laminaria sp., (Küpper et al., 1998 and refs. within) this seems unlikely in our $24 \mathrm{~h}$ incubations. Results from several other studies report the opposite effect, with increasing production seen in longer incubations (e.g. Bravo-Linares et al., 2010). It is possible that longer incubation times in enclosed systems may subject the algae to physiological stresses, such as nutrient depletion, build up of exudates or $\mathrm{pH}$ shifts, which may cause increases in halocarbon emissions (Mtolera et al., 1996). These varying results suggest that incubation effects may be species or incubation set up specific.

Our production rates for $\mathrm{CH}_{3} \mathrm{I}$ and $\mathrm{CHBr}_{3}$ were within the range of values quoted in the existing literature. For $\mathrm{CH}_{3} \mathrm{I}$ and $\mathrm{CHBr}_{3}$ all but one to two species (Papenfusiella kuromo (Itoh et al., 1997), Gracilaria cornea (Ekdahl et al., 1998), Bryopsis sp. and Caulerpa sp. (this study)) fell within \pm 1 SD around the mean for each class (red, brown, green). Methodological differences could have affected the emission rates recorded; for example Itoh et al. (1997) cut disks out of some algae samples for use in incubations which may have triggered defensive emissions leading to the high $\mathrm{CH}_{3} \mathrm{I}$ production observed.

Three genera which had been intensively studied, Fucus, Laminaria and Ulva, are highlighted in Fig. 6 to show variability within these groups. The spread of results recorded 

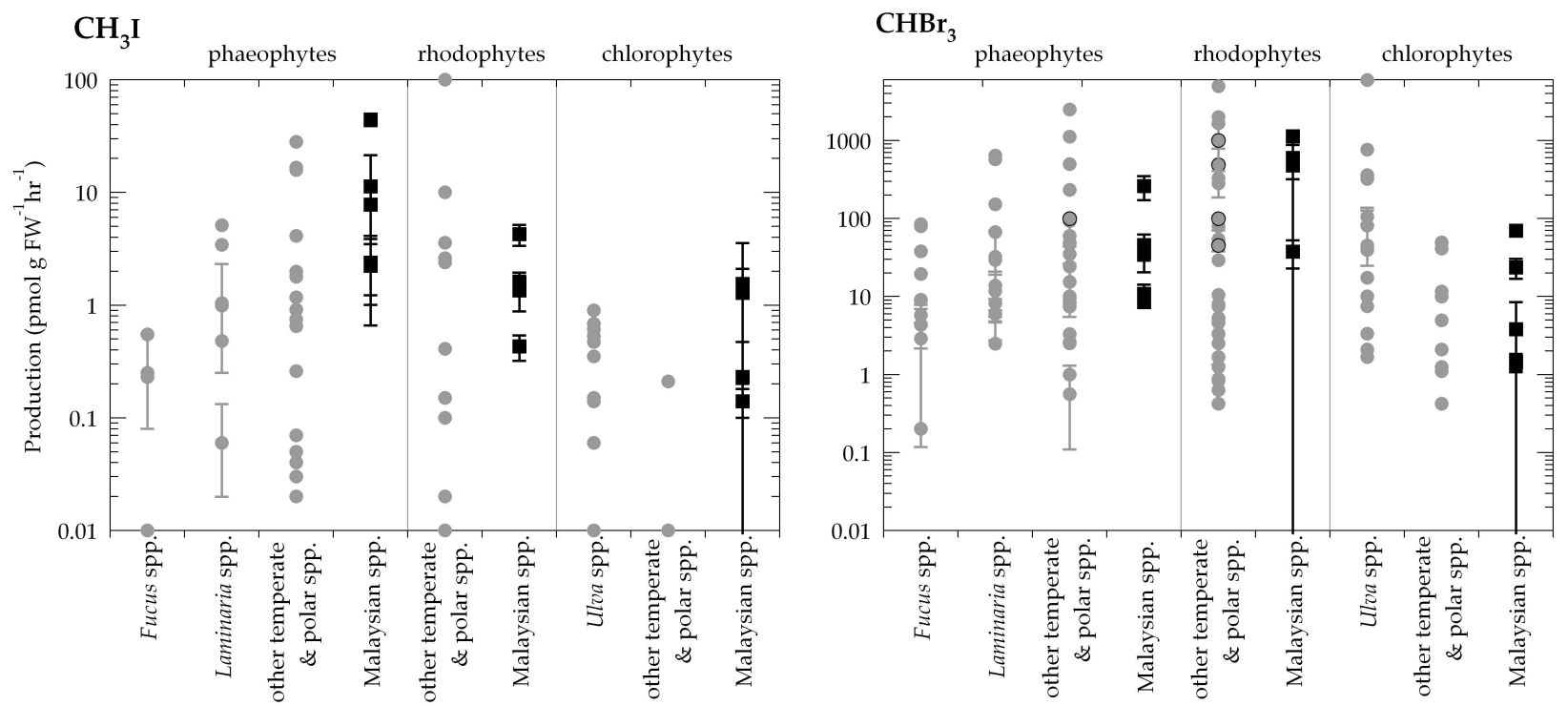

Fig. 6. Halocarbon production reported in this and previous studies for $\mathrm{CH}_{3} \mathrm{I}$ and $\mathrm{CHBr}_{3}$. $\mathbf{\square}=$ this study, error bars $=1 \sigma$ standard deviation. $\bullet=$ previous studies (black outline = study may include subtropical or tropical strains). Values from the literature are commonly mean values from 2-3 replicates, sometimes the median was quoted. Error bars, where shown, are for standard deviation or range of production values. Published values were from the following sources: Baker et al. (2001); Bravo-Linares et al. (2010); Carpenter et al. (2000); Collen et al. (1994); Ekdahl et al. (1998); Giese et al. (1999); Goodwin et al. (1997); Gschwend et al. (1985); Itoh and Shinya (1994); Itoh et al. (1997); Klick (1993); Laturnus (1996); Laturnus et al. (2004); Laturnus et al. (2010); Manley and Dastoor (1987); Manley et al. (1992); Marshall et al. (1999); Nightingale et al. (1995); Pedersen et al. (1996); Schall et al. (1994).

for species from these three genera measured from different locations and under different conditions is considerable. This variability is probably due to two factors. Firstly, differences in measurement techniques, such as incubation times, could impact calculated production, as discussed previously. Secondly, it is possible that species which share evolutionary traits, and so are grouped in the same genus, can demonstrate differences in physiology. Several studies have measured species from the same genus using the same experimental technique and seen large differences in $\mathrm{CHBr}_{3}$ production between species from the same or similar locations (Carpenter et al., 2000; Laturnus, 1996). Thereby, it seems possible that similar species from different locations could show differences in production rates beyond that which may be attributable to different experimental protocols.

\subsection{A semiquantitative analysis of the halocarbon flux from macroalgae}

The tropical region, especially the Pacific, has often been considered an important source region with regards to the global halocarbon budget. Tropical halocarbon fluxes have been proposed as globally important on the basis of observed high atmospheric mixing ratios and surface seawater concentrations and a proposed strong macroalgal source (Butler et al., 2007; Pyle et al., 2011; Yokouchi et al., 2005). As this study provided the first direct measurements of tropical macroalgal halocarbon production, the incubation-derived halocarbon production values were used to estimate regional fluxes of $\mathrm{CHBr}_{3}$ and compare these values to existing estimates. Papers referred to multiple times are abbreviated after first use for brevity. All data used in these estimates, alongside any assumptions or calculations made, are summarised in Supplement Table 2 and a comparison with other studies is made in Supplement Table 3.

\subsubsection{Determining macroalgal biomass}

To estimate macroalgal biomass along the Malaysian coastline, biomass transects conducted by UM at Port Dickson (Fig. 1) were used (Keng et al., 2013) (Keng13). Biomass evaluations were made several times over an 18 month period between March 2010 and June 2011. During each visit triplicate $100-130 \mathrm{~m}$ long transects each comprising 10 to 13 quadrats were conducted. All seaweed in each $0.09 \mathrm{~m}^{2}$ quadrat was collected and returned to the laboratory to determine total fresh and dry biomass as well as species abundance. Average biomass values during this 18 month period were 7.0, 5.2 and $0.1 \mathrm{~kg} \mathrm{FW} \mathrm{m}^{-2}$ for phaeophytes, chlorophytes and rhodophytes, respectively. No other published biomass data for the tropics could be found for comparison, however Hameed and Ahmed (1999) (HA99) measured localised biomass in a similar manner on the Pakistan coast and provided mean annual biomass values of 13.6, 11.0 and $4.1 \mathrm{~kg} \mathrm{FW} \mathrm{m}^{-2}$ for phaeophytes, chlorophytes and rhodophytes. Both studies show the same distribution 
of biomass: phaeophyte $>$ chlorophyte $>$ rhodophyte. However, total biomass per square kilometre from HA99 is roughly double that of Keng13. Previous studies estimating the contribution made by macroalgae to the global halocarbon flux (Gschwend et al., 1985; Nightingale et al., 1995) used biomass values determined from a 1975 FAO report (Michanek, 1975 - out of print, summary in Naylor, 1976) (Mich75) which estimated a global standing stock of phaeophyte and rhodophyte biomass of $1.5 \times 10^{10}$ and $2.7 \times 10^{9} \mathrm{~kg} \mathrm{FW}$, respectively. There are no data for chlorophytes in the Mich75 dataset, and it is biased to species that are harvested or farmed for commercial purposes. A comprehensive discussion of the Mich75 estimation and the errors attached to it, with regard to temperate coastlines, can be found in Carpenter and Liss (2000) (CL2000) who conclude that it is an underestimation. Charpy-Roubaud and Sournia (1990) defined a potential global coastal area inhabited by macroalgae of $6.8 \times 10^{12} \mathrm{~m}^{2}$. Attempts to distribute the global standing stock given by Mich75 over this area results in biomass estimates of $\sim 2.2 \times 10^{-3} \mathrm{~kg} \mathrm{FW} \mathrm{m}^{-2}$ for phaeophytes and $3.9 \times 10^{-4} \mathrm{~kg} \mathrm{FW} \mathrm{m}^{-2}$ for rhodophytes. These values are much lower than both the Keng13 and HA99 estimates. This is not unexpected as seaweed distribution is variable and errors would arise from scaling in either direction. On one hand, individual biomass studies are likely conducted in areas of high macroalgal biomass and therefore enhanced research potential. On the other, global standing stock estimates are difficult to reduce to regional biomass estimates, especially in the tropics where much of the current data is based on temperate and/or economic species. An example of a potential source of error when estimating halocarbon emissions can be seen in the significantly lower proportion of rhodophytes in the Keng13 database compared with both HA99 and Mitch75. We have shown tropical rhodophytes to be prolific producers of halocarbons and an overestimation of rhodophyte biomass could therefore lead to an overestimation in emission budgets. For these reasons, our ability to use local biomass data is of benefit to estimates made around Malaysia and, assuming similar species are found throughout South East Asia (Phang et al., 2008b), to a wider regional estimate as well.

\subsubsection{Determining regional fluxes and annual emissions}

To calculate the potential $\mathrm{CHBr}_{3}$ flux from tropical macroalgae, we assume that the coastal area covered by macroalgae extends $200 \mathrm{~m}$ from the shore with a constant gradient to a water depth of $6 \mathrm{~m}$. Whilst the Keng 13 biomass study extended to a maximum of $130 \mathrm{~m}$, for safety reasons, visual inspection confirmed seaweed beds extended out beyond this depth. We then defined three potential coastal scenarios. Within each scenario the following assumptions remained constant:
A1 We assume that seaweeds are distributed evenly within the base of the coastal zone (see diagram in Supplement Table 2) in the same amount per square metre as recorded in the Port Dickson transects. Tidal ranges are discussed further in individual scenarios. Errors on biomass studies (Keng13) were included in the error associated with our flux rate, see A2.

A2 We averaged production rates for phaeophytes, rhodophytes and chlorophytes from our incubations and multiplied this by the Keng13 biomass data to give a production rate of $378 \mathrm{nmolCHBr}_{3} \mathrm{~m}^{-2} \mathrm{~h}^{-1}$. The main errors on this flux rate come from the calculated production rates and the estimations of regional biomass from Keng13. To account for this, the individual standard deviations on species' production rates (Supplement Table 1) were propagated with the standard deviation error associated with the biomass studies over an 18 month period to give a percentage standard deviation (\% SD) error on our flux rate of $61 \%$ (flux rates $147-609 \mathrm{nmol} \mathrm{CHBr}_{3} \mathrm{~m}^{-2} \mathrm{~h}^{-1}$ ). This rate is similar to the $\sim 70 \%$ error on global $\mathrm{CHBr}_{3}$ annual emission from macroalgae given by Carpenter and Liss (2000). A large proportion of this error is due to intra-species variability observed in the incubation experiments (see Sect. 3.2) and the patchy distribution of rhodophytes at the Port Dickson sampling site. This error is discussed further in the following sections as we use this flux rate to determine regional emission estimates.

A3 Taking into account results from Carpenter et al. (2000) (Car2000) who show average diel production over a $24 \mathrm{~h}$ light dark cycle to be only $60 \%$ of that under constant illumination we reduce our production values, which were determined under constant light, by the same amount.

A4 Where emissions are into seawater, we assume instant mixing within this volume of water. We assume that the flux to the atmosphere is the major loss process for $\mathrm{CHBr}_{3}$ in seawater since it has a long lifetime in seawater relative to all other known loss processes; hydrolysis, biotic and abiotic reductive dehalogenation, halogen substitution and photolysis (see CL2000; Quack and Wallace, 2003 (QW03) and references therein).

A5 Flux calculations were made using mean seawater concentrations calculated in each scenario and Eqs. (1) and (2) below; where $K_{\mathrm{w}}$ is the transfer velocity expressed from the liquid phase and $\Delta C$ is the concentration difference between the liquid $\left(C_{\mathrm{w}}\right)$ and gaseous $\left(C_{\mathrm{a}}\right)$ phases. A mean atmospheric concentration of $3.2 \mathrm{ppt}$ was determined from air samples taken over coastal seawater as part of the EU SHIVA project. The SHIVA field campaign, which took place in Malaysian Borneo in November 2011, used a small boat to take air 
samples directly above the ocean surface along transects out to $20 \mathrm{~km}$ from the shore. Air samples were returned to UEA for analysis via GCMS. The range of $\mathrm{CHBr}_{3}$ concentrations measured was $0.9-6$ ppt. A sensitivity analysis showed that high seawater concentrations (see Scenario 1) dominate the flux and that altering the atmospheric concentration within the range observed during SHIVA has little effect on the calculated flux rate. The dimensionless Henry's Law constant $(H)$ was calculated using a mean $10^{\circ} \mathrm{N}-10^{\circ} \mathrm{S}$ latitudinal water temperature of $27^{\circ} \mathrm{C}$ and a mean oceanic surface wind speed of $5.5 \mathrm{~m} \mathrm{~s}^{-1}$ (QW03) and the procedure described in Johnson (2010).

$$
\begin{aligned}
& \text { Flux }=-K_{\mathrm{w}} \Delta C \\
& \Delta C=\frac{C_{\mathrm{a}}}{H}-C_{\mathrm{w}}
\end{aligned}
$$

A6 To estimate annual emissions from Malaysia and the South East Asian (SEA) region, we assume that, as our calculations include both a mean annual seaweed biomass and a correction for reduced halocarbon production during darkness, our fluxes remain constant throughout the year. We use coastal lengths from the World Resources Institute (WRI, 2012) who provide comparable data for all countries discussed in this study. Our definition of SEA includes the coastline of the following countries: Brunei, Burma, Cambodia, Christmas Island, Indonesia, Malaysia (both peninsular and eastern), the Philippines, Singapore, Thailand, Timor-Leste and Vietnam. Based on our limited visual experience we make the assumption that just under half the coastline supports seaweed in the Malaysian/SEA region. We assume that an even distribution of macroalgae exists within this area, in the density reported by Keng 13 .

- Scenario 1: Seaweeds are never exposed at low tide and emit constantly into the "wedge" of water extending $200 \mathrm{~m}$ from the shore to a maximum depth of $6 \mathrm{~m}$, a volume of $6 \times 10^{5} \mathrm{dm}^{3}$ for every metre of coastline. We assume the volume of seawater remains constant but refer to the Car2000 methodology whose calculations suggest that, due to tidal flushing, the daily mean $\mathrm{CHBr}_{3}$ concentration in the seawater wedge is similar to that which would be seen after $6 \mathrm{~h}$ of constant emissions into the seawater. This may be somewhat of an overestimate due to a larger tidal range in Car2000; $3 \mathrm{~m}$ at Mace Head compared to $1.7 \mathrm{~m}$ at Port Dickson. Following this technique we estimate a mean daily $\mathrm{CHBr}_{3}$ concentration of $755 \mathrm{pmol} \mathrm{dm}^{-3}$. This is within the range of coastal values given by QW03 of $36-2000 \mathrm{pmol} \mathrm{dm}^{-3}$. It is higher than preliminary measurements we made in 2010 which showed concentrations up to $410 \mathrm{pmol} \mathrm{dm}^{-3}$ over seaweed beds at Port Dickson, as well as the $388 \mathrm{pmol} \mathrm{dm}^{-3}$ mean reported by Car2000 from measurements at Mace Head, Ireland (Supplement Table 3). However, their assumption was that a depth of $10 \mathrm{~m}$ was reached $200 \mathrm{~m}$ from the shore. Increasing our water depth to $10 \mathrm{~m}$ would reduce our seawater concentration to $454 \mathrm{pmol} \mathrm{dm}^{-3}$, closer to the Car2000 value. The resulting mean $\mathrm{CHBr}_{3}$ flux from Malaysian coastal seawater influenced by seaweed beds to the atmosphere is $45(17-73) \mathrm{nmolCHBr}_{3} \mathrm{~m}^{-2} \mathrm{~h}^{-1}$. Scaling this up to cover Malaysia and SEA (using A6) we calculate an annual flux of 1(0.3-1.4) Mmol $\mathrm{Bryr}^{-1}$ for Malaysia and 15 (6-27) $\mathrm{Mmol} \mathrm{Bryr}^{-1}$ for SEA (Mmol is $10^{6}$ moles).

- Scenario 2: In this scenario a tidal cycle is applied to the same coastal wedge. Between $0-50 \mathrm{~m}$ from the shore macroalgae beds are periodically exposed and submerged during a semi-diurnal tidal cycle. Between 50$200 \mathrm{~m}$ the macroalgae remain constantly submerged. The volume of water within the entire $200 \mathrm{~m}$ wedge fluctuates with the tidal cycle, with a maximum tidal range of $1.7 \mathrm{~m}$. We assume that, when exposed, the average production rate of $378 \mathrm{nmolCHBr}_{3} \mathrm{~m}^{-2} \mathrm{~h}^{-1}$ $( \pm 61 \% \mathrm{SD}, \mathrm{A} 2)$ is emitted directly to the atmosphere and when submerged a flux rate is calculated using A5. Scaling up this flux rate using A6 gives an annual emission from Malaysia and SEA of 2 and $40 \mathrm{Mmol} \mathrm{Br} \mathrm{yr}^{-1}$, respectively.

- Scenario 3: In Scenarios 1 and 2 an assumption is made that $\mathrm{CHBr}_{3}$ flushed from the coastal wedge during the tidal cycle is effectively lost and does not reach the atmosphere. However, as the lifetime of $\mathrm{CHBr}_{3}$ in seawater is on the order of several years (see Carpenter et al., 2009 (Car09); Hense and Quack, 2009) $\mathrm{CHBr}_{3}$ flushed from this coastal wedge may still evade to the atmosphere. With this in mind, Scenario 3 assumes all emissions from seaweed (at a rate of $378( \pm 61 \% \mathrm{SD}) \mathrm{nmol} \mathrm{CHBr} 3 \mathrm{~m}^{-2} \mathrm{~h}^{-1}$ (A2)) enters the atmosphere without an intermediate step via seawater. This represents an upper limit estimation and, when combined with Scenarios 1 and 2, provides a flux rate range to compare to other studies. The annual emissions from Scenario 3 for Malaysia and SEA are 7 (3-12) and 140 (53-224) $\mathrm{Mmol} \mathrm{Br} \mathrm{yr}^{-1}$, respectively.

\subsubsection{A comparison of estimated fluxes and emissions}

The idealised scenarios described above place bounds on the likely coastal emissions from the SEA region and provide some measure of uncertainty (due to the many assumptions involved) when comparisons are made with previous estimates. Incorporating Scenarios 1-3, which include the combined errors on calculated production rate and observed biomass distributions (A2), we give a final estimated flux rate range of $17-610 \mathrm{nmol} \mathrm{CHBr}_{3} \mathrm{~m}^{-2} \mathrm{~h}^{-1}$. Comparisons between flux rate estimates should be made with caution as 
different studies use different flux calculations. Numerous factors can affect calculated fluxes, including approximations of wind speed, Schmidt number and $\mathrm{CHBr}_{3}$ diffusivity. However, if we compare our flux rate range to the median global coastal flux derived by QW03 of $101 \mathrm{nmol} \mathrm{CHBr}_{3} \mathrm{~m}^{-2} \mathrm{~h}^{-1}$ and their global range of $4-430 \mathrm{nmol} \mathrm{CHBr}_{3} \mathrm{~m}^{-2} \mathrm{~h}^{-1}$, our values are not too dissimilar. Our upper estimate falls above theirs, however, our upper limit is based upon an assumption that all $\mathrm{CHBr}_{3}$ produced by macroalgae reaches the atmosphere, a likely overestimate due to seawater loss processes (see A5). The QW03 data were heavily biased towards measurements in temperate and polar regions and many were taken within the Atlantic, so this comparison suggests that tropical coastlines are not outliers in terms of global coastal fluxes. Comparisons can also be made with Car09 who give a temperate $\left(50-60^{\circ} \mathrm{N}\right)$ coastal flux rate of $10(5-13) \mathrm{nmol} \mathrm{CHBr}_{3} \mathrm{~m}^{-2} \mathrm{~h}^{-1}$ and Butler et al. (2007) (BTL07) who provide an average global coastal flux rate of $9(<0.1-21) \mathrm{nmol} \mathrm{CHBr}_{3} \mathrm{~m}^{-2} \mathrm{~h}^{-1}$. These flux rates both fall below our Scenario 1 lower estimate, however both datasets are from research ship cruises which are very unlikely to represent waters directly influenced by macroalgae emissions well. The potential importance of macroalgae in determining coastal fluxes can be seen in a comparison with observations from the Cape Verde observatory $\left(16.8^{\circ} \mathrm{N}, 24.9^{\circ} \mathrm{W}\right.$, tropical Atlantic) where intertidal seaweeds are not abundant. A localised flux rate of $7 \mathrm{nmol} \mathrm{m}^{-2} \mathrm{~h}^{-1}$, derived by O'Brien et al. (2009) from model studies attempting to replicate local sources of observed high atmospheric $\mathrm{CHBr}_{3}$ concentrations observed at Cape Verde, is also lower than our range. In addition, our flux rates are higher than a range of open ocean $\mathrm{CHBr}_{3}$ flux rates of $0.1-0.5 \mathrm{nmol} \mathrm{CHBr}_{3} \mathrm{~m}^{-2} \mathrm{~h}^{-1}$ (BTL07; QW03; Tegtmeier et al., 2012) (Supplement Table 3). Our calculations suggest that in the tropics, as in temperate regions, there is a higher flux rate in a narrow coastal region compared to the open ocean.

A collection of flux rates should be accompanied by estimates of total annual emissions for meaningful comparisons; a high flux in a narrow coastal band may contribute less than a lower open ocean flux covering a large area. No other nation-specific data are available for comparison with our calculated Malaysian emissions, but Pyle et al. (2011) (Pyle11) used atmospheric $\mathrm{CHBr}_{3}$ measurements from inland and coastal sites with back trajectory and chemical transport models to estimate SEA regional emissions. They calculated an annual emission from their SEA region of between $180-350 \mathrm{Mmol} \mathrm{Br} \mathrm{yr}^{-1}$ (assuming their "Scenario 5" emissions are distributed evenly between coastal and open ocean regions). These values are lower than original estimates using a similar model with a coarser spatial resolution (Warwick et al., 2006) which predicted $\sim 7050 \mathrm{Mmol} \mathrm{CHBr}_{3} \mathrm{yr}^{-1}$ using similar scenarios. This earlier study suggested that the tropics must be a dominant source of halocarbon emissions in order to account for the observed atmospheric distribution of $\mathrm{CHBr}_{3}$. Our SEA an-

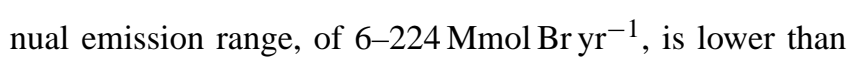
Pyle11, with our upper limit similar to their lower estimate. However, a number of differences between these studies could account for this disparity. Firstly, both studies define SEA differently, the Pyle11 SEA region covers a larger area and includes and more coastline than ours. Secondly, whilst they do not specify the coastal width used in their model it is likely larger than our $200 \mathrm{~m}$ strip (scenarios in Warwick et al., 2006, which remain similar in Pyle11, use data from QW03 who quote a coastal area up to $2 \mathrm{~km}$ from the shore). It is highly likely that strong seaweed-influenced fluxes are limited to a coastal zone much narrower than $2 \mathrm{~km}$, and should not be extrapolated to cover such a large coastal region. Elevated concentrations in shelf regions are potentially attributable to other sources (see QW03) and may need to be parameterised independently in model scenarios. This result highlights an important point made by Car09; that to compare coastal fluxes and emissions the community needs to create a standardised definition of coastal, shelf and open ocean zones.

If one compares our annual emissions to a wider dataset that provides global coastal annual emission estimates ranging from 1600 (CL2000) to 8100 (BTL07) $\mathrm{Mmol} \mathrm{Br} \mathrm{yr}^{-1}$ (Supplement Table 3) our upper limit (Scenario 3) SEA value provides between $2-9 \%$ of total coastal $\mathrm{CHBr}_{3}$ emissions. Previous studies have estimated that the contribution of tropical oceans to the global halocarbon budget is around $75 \%$ (Palmer and Reason, 2009 ( $\pm 46 \%$ ); Yang et al., 2005). Our lower value suggests other areas, such as the open oceans, may be important in terms of global $\mathrm{CHBr}_{3}$ emissions.

Several potential sources of error could affect our calculations which scale up biomass from one site to cover the SEA region. One example is the percentage of total macroalgal biomass comprised of phaeophytes, rhodophytes and chlorophytes. Data from Keng13 suggests rhodophyte biomass is $<1 \%$ of total seaweed biomass per square metre, yet rhodophytes were the dominant halocarbon producers during our incubation studies. For example, increasing rhodophyte biomass to $10 \%$ in Scenario 1 leads to a doubling of the Scenario 1 mean macrophyte flux rate from $45 \mathrm{nmol} \mathrm{CHBr}_{3} \mathrm{~m}^{-2} \mathrm{~h}^{-1}$ to $93 \mathrm{nmol} \mathrm{CHBr}_{3} \mathrm{~m}^{-2} \mathrm{~h}^{-1}$. This simple test highlights the benefit of conducting localised biomass studies alongside halocarbon production measurements. We also recognise, however, that Port Dickson was selected for this study in part because of prominent macroalgae colonisation. Other coastal areas we inspected along the western Malaysian shore were notably devoid of visible seaweed beds. Species selection was representative of common Malaysian species, including dominant genera such as Sargassum and Gracilaria, but a wide variety of species remain unquantified in terms of halocarbon emissions. For example, only 3 out of the 39 Malaysian Sargassum species recorded by Phang et al. (2008a) were incubated. It should also be recalled that macroalgae produce $\mathrm{CH}_{2} \mathrm{Br}_{2}$ and mixed bromochloro- compounds alongside $\mathrm{CHBr}_{3}$, these gases are 
also atmospherically important. Repeating the calculations made for $\mathrm{CHBr}_{3}$ (Sect. 3.5.2), we estimate the annual emission of $\mathrm{CH}_{2} \mathrm{Br}_{2}$ from SEA to be $\sim 2-136 \mathrm{Mmol} \mathrm{Br} \mathrm{yr}^{-1}$. This is not inconsiderable when compared to the same value for $\mathrm{CHBr}_{3}$, and when one considers the longer atmospheric lifetime of $\mathrm{CH}_{2} \mathrm{Br}_{2}$ and, therefore, its potential to dominate over $\mathrm{CHBr}_{3}$ in terms of the bromine from very short lived gases that reaches the stratosphere.

Upon consideration of all factors, it seems likely that macroalgae may play an important role in halocarbon budgets, regionally and within a narrow coastal band. However, across a larger coastal area halocarbon emissions from tropical coastal macroalgae cannot account for all of the annual emissions predicted by models.

\subsubsection{The impact of tropical aquaculture}

Having established estimates for current Malaysian/SEA emissions, it is of interest to consider how these are influenced by seaweed mariculture today and how this may change in the future. Rhodophyte genera such as Gracilaria, Gelidium and Kappaphycus, which were all found to emit large quantities of bromocarbons in this study, are commonly farmed for food or commercial products in SEA (John et al., 2011; McHugh, 2003).

As the seaweed found at Port Dickson is naturally occurring, we assume the parameters used to calculate regional biomass in the flux calculations, above, represent the natural biomass of Malaysia. We also estimate that current farmed seaweed biomass at $\sim 6000 \mathrm{t} \mathrm{DW} \mathrm{yr}^{-1}$ (Neish, 2009; Phang, 2010 ) is in addition to this, and that this biomass is made up completely of rhodophytes. Using these parameters to calculate halocarbon production from natural and farmed biomass we estimate that aquaculture currently makes up $0.7 \%$ of total Malaysian biomass but contributes $\sim 2 \%$ of Malaysian $\mathrm{CHBr}_{3}$ macroalgae emissions, due to the fact that farmed seaweeds in this region are rhodophytes which are strong emitters of bromocarbons. There is a strong interest in increasing the amount of seaweed aquaculture in Malaysia; various studies suggest the potential increase could lead to a 6 to 11-fold increase in the area under cultivation (Goh and Lee, 2010; Neish, 2009; Phang et al., 2010). These predictions are based upon recent increases in production as well as projections of total cultivatable area. Increases of this magnitude could occur within the next decade, based on recent increases in growth. If we assume naturally produced halocarbon emissions remain constant, this increase could lead to a corresponding increase in the relative contribution of $\mathrm{CHBr}_{3}$ emissions from aquaculture, making it responsible for 12$20 \%$ of total emissions from Malaysian macroalgae.

Clearly caveats must be applied to these calculations. We assume that errors in calculated halocarbon production rates for rhodophytes (see A2) apply equally to both natural and farmed algae. The percentage change estimates for the effects of aquaculture only consider production from macroalgae and not other potential coastal sources such as benthic microalgae, phytoplankton or mangroves. It is assumed that airsea gas exchange processes are equal for natural and farmed algae and that the rate of these processes will not change in the future. Many factors, some unique to the coastal region, mean determining coastal flux rates are difficult. These processes include wave damping, drag (in shallower waters the ocean floor will exert a greater effect), higher wind speeds, thermal stratification (increased warming by light on shallower waters), changes in salinity due to precipitation and increased surfactants (Upstill-Goddard, 2006 and references herein). Accurate emission budgets would also need to include emissions that may occur during harvesting and postharvest processing. We assume halocarbon production from natural and farmed algae is the same, despite the fact that an artificial aquaculture environment places increased physiological stress on the algae due to increased prevalence of pests, disease and/or herbivores; increased light stress and potential nutrient limitation (Ask and Azanza, 2002). It is also important to consider aquaculture on a global scale. Around $94 \%$ of seaweed production within the SEA region occurs in Indonesia and the Philippines (Phang et al., 2010) and market analyses suggest production in all SEA is likely to increase (Neish, 2009), with consequent increases in regional halocarbon emissions. There are also other important non-tropical producers. China is the world leader, harvesting 1.2 million tonnes (DW) of seaweed in 2007, over five times the amount produced in the entire SEA region (Tang et al., 2011). These potentially larger emissions are, however, at a distance from the region of tropical deep convective systems. The range of cultivated species also differs; China produces mainly Laminaria, a strong producer of iodinated species, and Porphyra (Tang et al., 2011), so the impact on local atmospheric chemistry may also vary between the two regions.

\section{Conclusions}

1. Incubations of 15 tropical macroalgae species showed variable production rates covering several orders of magnitude. Brominated halocarbons were dominant, and rhodophytes produced the most bromocarbons. Phaeophytes and chlorophytes showed a stronger propensity towards iodocarbon production, although emissions in general were low for the majority of chlorophytes we studied.

2. Our measurements at two time points during a $24 \mathrm{~h}$ incubation demonstrate that incubation time can also have an impact on determined production rates; production rates were higher at $t 4$ compared to $t 24$. For this reason, comparisons between individual studies should be made with caution.

3. Nonetheless, data from previous studies were compared to our tropical data and the range of production values 
was similar. As the tropical dataset is considerably smaller than for polar and temperate species, only preliminary conclusions may be drawn at this time. However, from our dataset it seems that tropical species are, on average, not individually stronger producers of halocarbons than their temperate and polar counterparts. Differences in species distribution may, instead, drive geographical differences in regional coastal halocarbon emissions; for example, a higher propensity toward stronger-producing rhodophytes (natural or farmed) in tropical regions.

4. $\mathrm{CHBr}_{3}$ fluxes and corresponding annual emission rates from the SEA coastal environment were investigated and our emission estimates fall at the lower range of published data. It seems likely that the contribution made by macroalgae to the regional SEA coastal halocarbon budget is smaller than previously estimated.

5. Current aquaculture is a minor contribution to Malaysian $\mathrm{CHBr}_{3}$ emissions. However, projected increases in aquaculture could lead to an increasingly important contribution, especially if aquaculture growth is mirrored in neighbouring countries with significant aquaculture industries.

6. The SEA region is one of rapid environmental change; aquaculture, mangrove destruction and urban pollution may all influence coastal biology and therefore halocarbon emissions. Due to the potential importance of this area as a source region for stratospheric bromine, quantifying emissions from this area and understanding how they may change in the future will make an important contribution to our understanding of global halogen budgets. In particular, a need for in situ measurements of halocarbon concentrations in SEA coastal seawater would help strengthen estimates of fluxes and annual emissions from this region.

\section{Supplementary material related to this article is available online at: http://www.biogeosciences.net/10/ 3615/2013/bg-10-3615-2013-supplement.zip.}

Acknowledgements. This work would not have been possible without substantial help from the Institute of Ocean and Earth Sciences (IOES) at the University of Malaya (UM) for hosting University of East Anglia (UEA) staff during fieldwork. Their assistance (with particular thanks to H. Y. Yeong) with logistical help, sample collection, species identification and biomass distribution data was invaluable. M. Johnson (UEA) provided help and guidance with the flux estimates. E. L. is funded by a NERC Ph.D. studentship (ID E66107B). Financial assistance was also provided by the EU SHIVA Project (226224-FP7-ENV-2008-1).

Edited by: C. Robinson

\section{References}

Ask, E. I. and Azanza, R. V.: Advances in cultivation technology of commercial eucheumatoid species: a review with suggestions for future research, Aquaculture, 206, 257-277, doi:10.1016/S00448486(01)00724-4, 2002.

Baker, J. M., Sturges, W. T., Sugier, J., Sunnenberg, G., Lovett, A. A., Reeves, C. E., Nightingale, P. D., and Penkett, S. A.: Emissions of $\mathrm{CH}_{3} \mathrm{Br}$, organochlorines, and organoiodines from temperate macroalgae, Chemosphere, 3, 93-106, 2001.

Ball, S. M., Hollingsworth, A. M., Humbles, J., Leblanc, C., Potin, P., and McFiggans, G.: Spectroscopic studies of molecular iodine emitted into the gas phase by seaweed, Atmos. Chem. Phys., 10, 6237-6254, doi:10.5194/acp-10-6237-2010, 2010.

Bondu, S., Cocquempot, B., Deslandes, E,. and Morin, P.: Effects of salt and light stress on the release of volatile halogenated organic compounds by Solieria chordalis: a laboratory incubation study, Botanica Marina, 51, 485-492, doi:10.1515/BOT.2008.056, 2008.

Bravo-Linares, C. M., Mudge, S. M., and Loyola-Sepulveda, R. H.: Production of volatile organic compounds (VOCs) by temperate macroalgae: the use of solid phase microextraction (SPME) coupled To GC-MS as method of analysis, J. Chil. Chem. Soc., 55, 227-232, doi:10.4067/S0717-97072010000200018, 2010.

Butler, J., King, D. B., Lobert, J. M., Montzka, S. A., YvonLewis, S. A., Hall, B. D., Warwick, N. J., Mondeel, D. J., Aydin, M., and Elkins, J. W.: Oceanic distributions and emissions of short-lived halocarbons, Global Biogeochem. Cy., 21, GB1023, doi:10.1029/2006GB002732, 2007.

Carpenter, L. and Liss, P.: On temperate sources of bromoform and other reactive organic bromine gases, J. Geophys. Res., 105, 20539-20547, doi:10.1029/2000JD900242, 2000.

Carpenter, L. J., Malin, G., Liss, P. S., and Küpper, F.C.: Novel biogenic iodine-containing trihalomethanes and other short-lived halocarbons in the coastal East Atlantic, Global Biogeochem. Cy., 14, 1191-1204, 2000.

Carpenter, L. J., Jones, C. E., Dunk, R. M., Hornsby, K. E., and Woeltjen, J.: Air-sea fluxes of biogenic bromine from the tropical and North Atlantic Ocean, Atmos. Chem. Phys., 9, 1805-1816, doi:10.5194/acp-9-1805-2009, 2009.

Chance, R., Baker, A. R., Küpper, F. C., Hughes, C., Kloareg, B., and Malin, G.: Release and transformations of inorganic iodine by marine macroalgae, Estuar. Coast. Shelf Sci., 82, 406-414, doi:10.1016/j.ecss.2009.02.004, 2009.

Charpy-Roubaud, C. and Sournia, A.: The comparative estimation of phytoplanktonic, microphytobenthic and macrophytobenthic primary production in the oceans, Mar. Microb. Food Webs, 4, 31-57, 1990.

Collen, J., Ekdahl, A., Abrahamsson, K., and Pedersen, M.: The involvement of hydrogen peroxide in the production of volatile halogenated compounds by, Phytochemistry, 36, 1197-1202, 1994.

Cronin, G., Paul, V. J., Hay, M. E., and Fenical, W.: Are tropical herbivores more resistant than temperate herbivores to seaweed chemical defenses? Diterpenoid metabolites from Dictyota acutiloba as feeding deterrents for tropical versus temperate fishes and urchins, J. Chem. Ecol., 23, 289-302, 1997.

Dorf, M., Butz, A., Camy-Peyret, C., Chipperfield, M. P., Kritten, L., and Pfeilsticker, K.: Bromine in the tropical troposphere and stratosphere as derived from balloon-borne $\mathrm{BrO}$ observations, 
Atmos. Chem. Phys., 8, 7265-7271, doi:10.5194/acp-8-72652008, 2008.

Ekdahl, A., Pedersen, M., and Abrahamsson, K.: A study of the diurnal variation of biogenic volatile halocarbons, Mar. Chem., 63, 1-8, 1998.

Giese, B., Laturnus F., Adams, F. C., and Wiencke, C.: Release of volatile iodinated $\mathrm{C} 1-\mathrm{C} 4$ hydrocarbons by marine macroalgae from various climate zones, Environ. Sci. Technol., 33, 24322439, 1999.

Goh, C. S. and Lee, K. T.: A visionary and conceptual macroalgae-based third-generation bioethanol (TGB) biorefinery in Sabah, Malaysia as an underlay for renewable and sustainable development, Renewable Sust. Energ. Rev., 14, 842-848, doi:10.1016/j.rser.2009.10.001, 2010.

Goodwin, K. D., North, W. J., and Lidstrom, M. E.: Production of bromoform and dibromomethane by Giant Kelp: Factors affecting release and comparison to anthropogenic bromine sources, Limnol. Oceanogr., 42, 1725-1734, doi:10.4319/lo.1997.42.8.1725, 1997.

Graham, M. H., Kinlan, B. P., Druehl, L. D., Garske, L. E., and Banks, S.: Deep-water help refugia as potential hotspots of tropical marine diversity and productivity, P. Natl. Acad. Sci., 104, 16576-16580, 2007.

Gschwend, P. M., MacFarlane, J. K., and Newman, K. A.: Volatile halogenated organic compounds released to seawater from temperate Marine Macroalgae, Science, 227, 1033-1035, 1985.

Hameed, S. and Ahmed, M.: Seasonal variation in seaweed biomass from the rocky shore of Pacha, near Karachi, Pakistan (Arabian Sea), Pakistan J. Biol. Sci., 2, 1044-1052, 1999.

Hense, I. and Quack, B.: Modelling the vertical distribution of bromoform in the upper water column of the tropical Atlantic Ocean, Biogeosciences, 6, 535-544, doi:10.5194/bg-6-535-2009, 2009.

Hughes, C., Malin, G., Nightingale, P. D., and Liss, P. S.: The effect of light stress on the release of volatile iodocarbons by three species of marine microalgae, Limnol. Oceanogr., 51, 28492854, 2006.

Hughes, C., Franklin, D. J., and Malin, G.: Iodomethane production by two important marine cyanobacteria: Prochlorococcus marinus (CCMP 2389) and Synechococcus sp. (CCMP 2370), Mar. Chem., 125, 19-25, doi:10.1016/j.marchem.2011.01.007, 2011.

Itoh, N. and Shinya, M.: Seasonal evolution of bromomethanes from coralline algae (Corallinaceae) and its effect on atmospheric ozone, Mar. Chem., 45, 95-103, doi:10.1016/03044203(94)90094-9, 1994.

Itoh, N., Tsujita, M., Ando, T., Hisatomi, G., and Higashi, T.: Formation and emission of monohalomethanes from marine algae, Phytochemistry, 45, 67-73, 1997.

John, R. P., Anisha, G. S., Nampoothiri, K. M., and Pandey, A.: Micro and macroalgal biomass: a renewable source for bioethanol, Bioresource Technol., 102, 186-193, doi:10.1016/j.biortech.2010.06.139, 2011.

Johnson, M. T.: A numerical scheme to calculate temperature and salinity dependent air-water transfer velocities for any gas, Ocean Sci., 6, 913-932, doi:10.5194/os-6-913-2010, 2010.

Jones, C. E. and Carpenter, L. J.: Solar photolysis of $\mathrm{CH}_{2} \mathrm{I}_{2}$, $\mathrm{CH}_{2} \mathrm{ICl}$, and $\mathrm{CH}_{2} \mathrm{IBr}$ in water, saltwater, and seawater, Environ. Sci. Technol., 39, 6130-6137, 2005.

Keng, F. S.-L., Phang, S.-M., Raman, N., Leedham, E. C., Hughes, C., Robinson, A. D., Harris, N. R. S., Pyle, J. A., and Sturges, W.
T.: Volatile halocarbon emissions by three tropical brown seaweeds under different light intensities, J. Appl. Phycol., in press, doi:10.1007/s10811-013-9990-x, 2013.

Klick, S.: The release of volatile halocarbons to seawater by untreated and heavy metal exposed samples of the brown seaweed Fucus vesiculosus, Mar. Chem., 42, 211-221, doi:10.1016/03044203(93)90013-E, 1993.

Küpper, F. C., Schweigert, N., Ar Gall, E., Legendre, J.-M., Vilter, H., and Kloareg, B.: Iodine uptake in Laminariales involves extracellular, haloperoxidase-mediated oxidation of iodide, Planta, 207, 163-171, 1998.

Küpper, F. C., Carpenter, L. J., McFiggans, G. B., Palmer, C. J., Waite, T. J., Boneberg, E.-M., Woitsch, S., Weiller, M., Abela, R., Grolimund, D., Potin, P., Butler, A., Luther, G. W., Kroneck, P. M. H., Meyer-Klaucke, W., and Feiters, M. C.: Iodide accumulation provides kelp with an inorganic antioxidant impacting atmospheric chemistry, P. Natl. Acad. Sci. USA, 105, 6954-6958, doi:10.1073/pnas.0709959105, 2008.

La Barre, S., Potin, P., Leblanc, C., and Delage, L.: The halogenated metabolism of brown algae (Phaeophyta), its biological importance and its environmental significance, Mar. Drugs, 8, 9881010, doi:10.3390/md8040988, 2010.

Laturnus, F.: Release of volatile halogenated organic compounds by unialgal cultures of polar macroalgae, Chemosphere, 31, 33873395, 1995.

Laturnus, F.: Volatile halocarbons released from Arctic macroalgae, Mar. Chem., 55, 359-366, doi:10.1016/S0304-4203(97)89401-7, 1996.

Laturnus, F., Svensson, T., Wiencke, C., and Oberg, G.: Ultraviolet radiation affects emission of ozone-depleting substances by marine macroalgae: results from a laboratory incubation study, Envir. Sci. Tech., 38, 6605-6609, 2004.

Laturnus, F., Svensson, T., and Wiencke, C.: Release of reactive organic halogens by the brown macroalga Saccharina latissima after exposure to ultraviolet radiation, Polar Res., 29, 379-384, doi:10.1111/j.1751-8369.2010.00167.x, 2010.

Mairh, O. P., Ramavat, B. K., Tewari, A., Oza, R. M., and Joshi, H. V.: Seasonal variation, bioaccumulation and prevention of loss of iodine in seaweeds, Phytochemistry, 28, 3307-3310, 1989.

Mäkelä, J., Hoffman, T., Holzke, C., Väkevä, M., Suni, T., Mattila, T., Aalto, P. P., Tapper, U., Kauppinen, E. I., and O’Dowd, C. D.: Biogenic iodine emissions and identification of end-products in coastal ultrafine particles during nucleation bursts, J. Geophys. Res., 107, 8110, doi:10.1029/2001JD000580 2002.

Manley, S. L.: Phytogenesis of halomethanes: A product of selection or a metabolic accident?, Biogeochemistry, 60, 163-180, 2002.

Manley, S. L. and Dastoor, M. N.: Methyl halide $\left(\mathrm{CH}_{3} \mathrm{X}\right)$ production from the giant kelp, Macrocystis, and estimates of global $\mathrm{CH}_{3} \mathrm{X}$ production by kelp, Limnol. Oceanogr., 32, 709-715, 1987.

Manley, S. L. and Dastoor, M. N.: Methyl iodide $\left(\mathrm{CH}_{3} \mathrm{I}\right)$ production by kelp and associated microbes, Mar. Biol., 98, 477-482, 1988

Manley, S. L., Goodwin, K., and North, W. J.: Laboratory production of bromoform, methylene bromide and methyl iodide by macroalgae and distribution in nearshore southern California waters, Limnol. Oceanogr., 37, 1652-1659, 1992.

Marshall, R., Harper, D., McRoberts, W., and Dring, M. T.: Volatile bromocarbons produced by Falkenbergia stages of Asparagopsis 
spp. (Rhodophyta), Limnol. Oceanogr., 44, 1348-1352, 1999.

Mata, L., Gaspar, H., and Santos, R.: Carbon/nutrient balance in relation to biomass production and halogenated compound content in the red alga Asparagopsis Taxiformis (Bonnemaisoniaceae), J. Phycol., 47, 248-253, doi:10.1111/j.1529-8817.2011.01083.x, 2011.

McHugh, D. J.: A guide to the seaweed industry. Food and Agriculture Organisation (FAO), Canberra, FAO Fisheries Technical Paper No. 441, 2003.

Michanek, G.: Seaweed resources of the ocean, FAO, FAO Fish. Tech. Pap. No. 138, 1975.

Montzka, S. A. and Reimann, S. (coordinating lead authors), Engel, A., Kruger, K., O'Doherty, S., Sturges, W. T., Blake, D., Dorf, M., Fraser, P., Friodevaux, L., Jucks, K., Kreher, K., Kurylo, M. J., Miller, J., Neilson, O.-J., Orkin, V. L., Prinn, R. G., Rhew, R., Santee, M. L., Stohl, A., and Verdonik, D.: Ozone-Depleting Substances (ODSs) and Related Chemicals, Chapter 1 in Scientific Assessment of Ozone Depletion 2010, Global Ozone Research and Monitoring Project Report No. 52, World Meteorological Organisation, Geneva, Switzerland, 2011

Moore, R. M., Geen, C. E., and Tait, V. K.: Determination of Henry's Law constants for a suite of naturally occurring halogenated methanes in seawater, Chemosphere, 30, 1183-1191, 1995.

Mtolera, M., Collén, J., Pedersén, M., Ekdahl, A., Abrahamsson, K., and Semesi, A. K.: Stress-induced production of volatile halogenated organic compounds in Eucheuma denticulatum (Rhodophyta) caused by elevated $\mathrm{pH}$ and high light intensities, Eur. J. Phycol., 31, 89-95, 1996

Naylor, J.: Production, trade and utilisation of seaweeds and seaweed products. FAO, FAO Fish. Tech. Pap. No. 159, 1976.

Neish, I. C.: Tropical red seaweeds as a foundation for integrated multi-trophic aquaculture (IMTA), The South East Asia Seaplant Network, Indonesia, SeaPlant Monograph No. HB2E 209 V3., 2009.

Nightingale, P. D., Malin, G., and Liss, P. S.: Production of chloroform and other low molecular-weight halocarbons by some species of macroalgae, Limnol. Oceanogr., 40, 680-689, doi:10.4319/lo.1995.40.4.0680, 1995.

O’Brien, L. M., Harris, N. R. P., Robinson, A. D., Gostlow, B., Warwick, N., Yang, X., and Pyle, J. A.: Bromocarbons in the tropical marine boundary layer at the Cape Verde Observatory - measurements and modelling, Atmos. Chem. Phys., 9, 9083-9099, doi:10.5194/acp-9-9083-2009, 2009.

Palmer, C. J. and Reason, C. J.: Relationships of surface bromoform concentrations with mixed layer depth and salinity in the tropical oceans, Global Biogeochemical Cy., 23, GB2014, doi:10.1029/2008GB003338, 2009

Palmer, C. J., Anders, T. L., Carpenter, L. J., Küpper, F. C., and McFiggans, G. B.: Iodine and halocarbon response of Laminaria digitata to oxidative stress and links to atmospheric new particle production, Environ. Chem., 2, 282, doi:10.1071/EN05078, 2005.

Paul, C. and Pohnert, G.: Production and role of volatile halogenated compounds from marine algae, Nat. Prod. Rep., 28, 186195, doi:10.1039/c0np00043d, 2010.

Paul, V. J., Littler, M. M., Littler, D. S., and Fenical, W.: Evidence for chemical defense in tropical green alga Caulerpa ashmeadii (Caulerpaceae: Chlorophyta): Isolation of new bioactive sesquiterpenoids, J. Chem. Ecol., 13, 1171-1185, 1987.

Pedersen, M., Collen, J., Abrahamsson, K., and Ekdahl, A.: Production of halocarbons from seaweeds: an oxidative stress reaction, Sci. Mar., 60, 257-263, 1996.

Pedersen, M., Nejrup, L., Fredriksen, S., Christie, H., and Norderhaug, K.: Effects of wave exposure on population structure, demography, biomass and productivity of the kelp Laminaria hyperborea, Mar. Ecol.-Prog. Ser., 451, 45-60, doi:10.3354/meps09594, 2012.

Phang, S.-M., Wong, C. L., and Sim, M. C.: Checklist of Malaysian Sargassum species, in: Taxonomy of Southeast Asian Seaweeds. University of Malaya Monograph Series 2, edited by: Phang, S.M., Lewmanomont, K., and Lim, P.-E., Institute of Ocean and Earth Sciences (IOES), University of Malaya, Kuala Lumpur, 83-103, 2008a.

Phang, S.-M., Lewnamomont, K., and Lim, P.-E. (Eds.): Taxonomy of Southeast Asian Seaweeds. University of Malaya Monograph Series 2, Institute of Ocean and Earth Sciences (IOES), University of Malaya, Kuala Lumpur, 2008b.

Phang, S.-M., Yeong, H.-Y., Lim, P.-E., Nor, A. R., and Gan, K. T.: Commercial varieties of Kappaphycus and Eucheuma in Malaysia, Malaysian J. Sci., 29, 214-224, 2010.

Pyle, J. A., Ashfold, M. J., Harris, N. R. P., Robinson, A. D., Warwick, N. J., Carver, G. D., Gostlow, B., O’Brien, L. M., Manning, A. J., Phang, S. M., Yong, S. E., Leong, K. P., Ung, E. H., and Ong, S.: Bromoform in the tropical boundary layer of the Maritime Continent during OP3, Atmos. Chem. Phys., 11, 529-542, doi:10.5194/acp-11-529-2011, 2011.

Quack, B. and Suess, E.: Volatile halogenated hydrocarbons over the western Pacific $43^{\circ}$ and $4^{\circ}$ N, J. Geophys. Res., 104, $1663-$ 1678, 1999.

Quack, B. and Wallace, D. W. R.: Air-sea flux of bromoform: Controls, rates, and implications, Global Biogeochem. Cy., 17, 1023, doi:10.1029/2002GB001890, 2003.

Quack, B., Atlas, E., Petrick, G., Stroud, G., Schauffler, S., and Wallace, D. W. R.: Oceanic bromoform sources for the tropical atmosphere, Geophys. Res. Lett., 31, 23-26, doi:10.1029/2004GL020597, 2004.

Quack, B., Atlas, E., Petrick, G., and Wallace, D. W. R.: Bromoform and dibromomethane above the Mauritanian upwelling: Atmospheric distributions and oceanic emissions, J. Geophy. Res., 112, D09312, doi:10.1029/2006JD007614, 2007.

Saenko, G. N., Kravtosova, Y. Y., Ivanenko, V. V., and Sheludko, S. I.: Concentration of iodine and bromine by plants in the seas of Japan and Okhotsk, Mar. Biol., 47, 243-250, 1988.

Saiz-Lopez, A., Plane, J. M. C., Baker, A. R., Carpenter, L. J., von Glasow, R., Martín, J. C. G., McFiggans, G., and Saunders, R. W.: Atmospheric chemistry of iodine., Chem. Rev., 112, 17731804, doi:10.1021/cr200029u, 2012.

Salawich, R. J.: Biogenic bromine, Nature, 439, 275-277, doi:10.1029/2005JD006244, 2006.

Sander, R.: Compilation of Henry's Law constants for inorganic and organic species of potential importance in environmental chemistry, available at: http://www.henrys-law.org/, 1999.

Santelices, B., Bolton, J., and Meneses, I.: Marine algal communities, in: Marine Macroecology, edited by: Witman, J. D. and Roy, K., The University of Chicago Press, Chicago, 153-194, 2009.

Schall, C., Laturnus, F., and Heumann, K. G.: Biogenic volatile organoiodide and organobromine compounds released from po- 
lar macroalgae, Chemosphere, 28, 1315-1324, 1994.

Seitz, K., Buxmann, J., Pöhler, D., Sommer, T., Tschritter, J., Neary, T., O'Dowd, C., and Platt, U.: The spatial distribution of the reactive iodine species IO from simultaneous active and passive DOAS observations, Atmos. Chem. Phys., 10, 2117-2128, doi:10.5194/acp-10-2117-2010, 2010.

Tang, Q., Zhang, J., and Fang, J.: Shellfish and seaweed mariculture increase atmospheric $\mathrm{CO}_{2}$ absorption by coastal ecosystems, Mar. Ecol.-Prog. Ser., 424, 97-104, doi:10.3354/meps08979, 2011.

Tegtmeier, S., Krüger, K., Quack, B., Atlas, E. L., Pisso, I., Stohl, A., and Yang, X.: Emission and transport of bromocarbons: from the West Pacific ocean into the stratosphere, Atmos. Chem. Phys., 12, 10633-10648, doi:10.5194/acp-12-10633-2012, 2012.

Tokarczyk, R. and Moore, M.: Production of volatile organohalogens by phytoplankton cultures, Geophys. Res. Lett., 21, 285288, 1994.

Upstill-Goddard, R. C.: Air-sea gas exchange in the coastal zone, Estuar. Coast. Shelf Sci., 70, 388-404, doi:10.1016/j.ecss.2006.05.043, 2006.

Warwick, N. J., Pyle, J. A., Carver, G. D., Yang, X., Savage, N. H., O'Connor, F. M., and Cox, R. A.: Global modelling of biogenic bromocarbons, J. Geophys. Res., 111, 1-12, doi:10.1029/2006JD007264, 2006.

Weinberger, F., Coquempot, B., Forner, S., Morin, P., Kloareg, B., and Potin, P.: Different regulation of haloperoxidation during agar oligosaccharide-activated defence mechanisms in two related red algae, Gracilaria sp. and Gracilaria chilensis, J. Exp. Bot., 58, 4365-4372, doi:10.1093/jxb/erm303, 2007.
Wever R., Tromp, M. G. M., Krenn, B. E., Marjani, A., and van Tol, M.: Brominating activity of the seaweed Ascophyllum nodosum: Impacts on the biosphere, Environ. Sci. Technol., 25, 446-449, 1991.

Winter, J. M. and Moore, B. S.: Exploring the chemistry and biology of vanadium-dependent haloperoxidases, J. Biol. Chem., 284, 18577-18581, 2009.

World Resources Institute: Coastal and Marine Ecosystems Marine Jurisdictions: Coastline length, EarthTrends: Environmental Information, http://www.wri.org/project/earthtrends/text/ coastal-marine/variable-61.html, last access: 18 March 2012.

Wuosmaa, A. M. and Hager, L. P.: Methyl chloride transferase: a carbocation route for biosynthesis of halometabolites, Science, 249, 160-162, 1990.

Yang, X., Cox, R., Warwick, N. J., Pyle, J., Carver, G. D., O'Connor, F. M., and Savage, N. H.: Tropospheric bromine chemistry and its impacts on ozone: A model study, J. Geophys. Res., 110, D23311, doi:10.1029/2005JD006244, 2005.

Yokouchi, Y., Hasebe, F., Fujiwara, M., Takashima, H., Shiotani, M., Nishi, N., Kanaya, Y., Hashimoto, S., Fraser, P., ToomSauntry, D., Mukai, H., and Nojiri, Y.: Correlations and emission ratios among bromoform, dibromochloromethane, and dibromomethane in the atmosphere, J.Geophys. Res., 110, D23309, doi:10.1029/2005JD006303, 2005. 